\title{
Beyond Lawrence: Metaprivacy and Punishment
}

\section{Jamal Greene}

\author{
CONTENTS
}

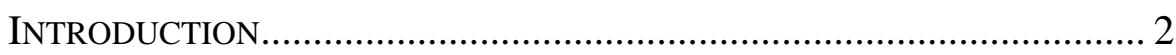

I. LAWRENCE V. TEXAS AND METAPRIVACY …………………............. 6

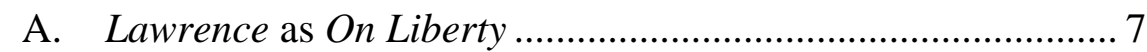

B. Lawrence as Metaprivacy .................................................... 11

1. On Desuetude ............................................................... 14

2. On Social Consensus......................................................... 16

3. On the Politics of Recognition ............................................ 18

II. Metaprivacy \& CRIMINAl SentenceS .................................... 20

A. The Constitutionality of Excessive Punishment ................... 21

1. When Is Excessiveness Unconstitutional? ......................... 22

2. Evaluating Excessiveness.................................................. 26

B. Metaprivacy \& Retribution ................................................... 28

1. Our Retribution Is Character-Based................................... 29

2. The Constitutionality of Character-Based Retribution ......33

3. Responding to Objections ................................................. 35

III. ON CONSTITUTIONAL FIT ....................................................... 41

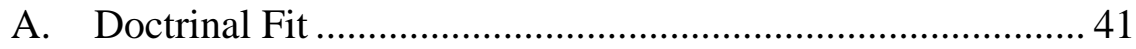

1. Constitutional Privacy ........................................................ 41

2. Hate Speech and the First Amendment ...............................55

B. The Presumptive Autonomy Ideal .......................................... 58

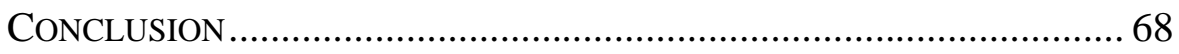


"[P]rivacy is nothing less than society's limiting principle."1

\section{INTRODUCTION}

Can the State kill someone for being a bad person? Consider the following Connecticut case: In 1997, Todd Rizzo, then eighteen years old, invited thirteen-year-old Stanley Edwards into his backyard, telling him that they would be hunting snakes. Once there, Rizzo straddled Edwards, in Rizzo's words, "like a horse," and struck him thirteen times with a sledgehammer as the boy pleaded for his life. He dumped the dead body in the woods nearby. Rizzo's motive? While stationed in Hawaii less than a year before the murder, the members of Rizzo's Marine platoon had been asked to list their ten goals in life. The second goal on Rizzo's list was "to kill a man." An avid student of past serial killings, Rizzo told police after he was taken into custody that he had bludgeoned Edwards to death because he wanted to see what it felt like. He pleaded guilty to capital murder and was sentenced to death in August 1999. ${ }^{2}$

I suspect that most Americans, regardless of their moral or legal stance on capital punishment, would at least deny any inconsistency in believing that the State may execute people like Todd Rizzo, and yet believing that it may not kill someone for being a bad person. It is not a difficult moral position to make out: Individuals are sentenced to death because they are convicted of committing heinous crimes, not because they are bad people, though the former may be strong evidence of the latter. The premise of this position is more complicated, however, than I have presented it. While being convicted of a heinous crime is a necessary precondition of a capital sentence, it is not a sufficient one. Many convicted of murder are not sentenced to death, and not only because of the capriciousness of sentencing juries or the serendipity of a plea bargain. In Woodson v. North Carolina, the Supreme Court found within the Eighth Amendment the notion that some convicts are more death-worthy than others. ${ }^{3}$ As such, no capital sentence since Woodson may be imposed without considering, in some fashion, ${ }^{4}$ those factors that aggravate and mitigate an individual's death-worthiness. Among the aggravating factors that were a but-for cause

\footnotetext{
${ }^{1}$ LAURENCE H. TRIBE, AMERICAN CONSTITUTIONAL LAW 1302 (2d ed. 1988).

${ }^{2}$ State v. Rizzo, 833 A.2d 363 (Conn. 2003).

${ }^{3}$ Woodson v. North Carolina, 428 U.S. 280 (1976).

${ }^{4}$ State schemes for considering aggravating and mitigating factors may be divided into two types. Under "weighing" schemes, aggravators and mitigators are balanced against each other. See, e.g., CAL. PEN. CODE $§ 190.3$ (2005). Under "threshold" schemes, jurors have the option of a death sentence so long as a single aggravator is present, but they are told that they must consider mitigating evidence. See, e.g., TEX. CODE CRIM. PROC. ANN. art. 37.071(b) (Vernon 2005).
} 
of Todd Rizzo's capital sentence were his "long-standing fascination with violent death and serial killers; his preexisting desire to kill; and the callous way in which he disposed of the victim's body." sentenced to death because he was found guilty of a heinous murder-that only explains his detention. He was sentenced to death because he had what Kant called "inner wickedness." $\mathrm{He}$ would be a prime candidate for a diagnostic label for which a number of psychiatrists have been agitating in recent years: clinically "evil.",

For most of America's constitutional history, the distinction between detention for conduct and detention for ontological status has not been legally relevant. That American courts did not scrutinize punishments for unconstitutional excess before the twentieth century provides a partial explanation, ${ }^{8}$ but the more important one is that we have viewed punishment for "inner wickedness" with skepticism during only a brief and recent epoch in our constitutional life. The homosexuality cases are paradigmatic. As late as 1986, the Court was "quite unwilling," in Bowers v. Hardwick, to "announce ... a fundamental right to engage in homosexual sodomy." Homosexual sex acts could be criminalized because the Court refused to acquiesce in the view that "majority sentiments about the morality of homosexuality should be declared inadequate." 10 The past nine years, however, have brought us Romer v. Evans, in which the Court declared that a Colorado constitutional amendment that prohibited the enactment of anti-discrimination laws that protected homosexuals and bisexuals violated the Equal Protection Clause, ${ }^{11}$ and Lawrence v. Texas, which affirmed the right of adults to engage in consensual homosexual relations in the privacy of their homes. ${ }^{12}$ Whatever its enduring contours, Lawrence seems at least to turn a suspicious eye towards arguments against conduct from pure moral illegitimacy.

This paper considers the extent to which the logic of Lawrence compels an inquiry into the constitutionality of incremental punishment based on character, focusing particularly on capital sentences. On Justice Kennedy's terms, Lawrence stands for the proposition that the State may not punish the

\footnotetext{
${ }^{5}$ Rizzo, 833 A.2d at 382.

${ }^{6}$ IMMANUEl KANT, THE METAPHYSICS OF MORALs 106 (Mary Gregor ed., 1996).

${ }^{7}$ See Benedict Carey, For the Worst of Us, the Diagnosis May Be 'Evil', N.Y. TIMES, Feb. 8, 2005 , at $\mathrm{F} 1$.

${ }^{8}$ See Weems v. United States, 217 U.S. 349 (1910) (holding, for the first time, a punishment unconstitutional under the Eighth Amendment).

${ }_{9}^{9} 478$ U.S. 186, 191 (1996).

${ }^{10} \mathrm{Id}$. at 196.

${ }^{11} 517$ U.S. 620 (1996).

12539 U.S. 558 (2003).
} 
conduct that "defines" an individual as homosexual, but need not endorse a homosexual lifestyle as legitimate, nor afford gay persons the same protection against invidious discrimination granted to those identified by race or sex. Writing this time for an outright majority, Justice Kennedy reaffirmed in Lawrence an opaque and controversial statement made by the plurality in Planned Parenthood v. Casey, that the Court's "obligation is to define the liberty of all, not to mandate [its] own moral code." 13 Without making any judgments into the rightness or wrongness of Lawrence's reasoning or holding, this paper scrutinizes what follows from taking Justice Kennedy at his word. I conclude that, subject to the inevitable retroactive tinkering of the common law, the character-based retributive rationale for capital punishment that the doctrine presently employs does not survive scrutiny under Lawrence because it is not ontologically neutral. That is, it depends intimately and therefore impermissibly on judgments about the punishment-worthiness of an individual's defining moral characteristics.

The paper proceeds as follows. Part I scrutinizes Lawrence itself in an effort to identify a non-arbitrary principle that justifies its result. Unless sui generis, a possibility that I address below, Lawrence may be justified by one of at least two broad, competing rationalizations. The first is the one Justice Scalia suggests in dissent, namely that the State may not criminalize "morals" offenses. ${ }^{14}$ This rationale would read into the Constitution some form of John Stuart Mill's "harm principle," the notion that an individual has an absolute right to perform either self-regarding acts or consensual acts affecting others. ${ }^{15}$ Section I.A rejects this view of Lawrence, and Section I.B argues for a second, more narrow, rationale for its holding - the proposition that conduct agreed by social consensus to be "selfdefinitional" cannot be punished for morality's sake. Punishment, that is, may be moral, but it must be impersonal. I term the right to remain free of government interference into one's transcendent identity a right to "metaprivacy."

Part II connects Lawrence's conception of metaprivacy to the particular form of retributive punishment countenanced by present doctrine. Section II.A establishes that excessive punishment is constitutionally defective and that capital punishment is susceptible to judicial review on the question of excessiveness. Section II.B gives doctrinal content to the elusive concept of retribution and argues that retributive punishment in action involves

\footnotetext{
${ }^{13}$ Lawrence, 539 U.S. at 571 (quoting Planned Parenthood v. Casey, 505 U.S. 833, 850 (1992) (plurality opinion)).

${ }^{14} I d$. at 590 (Scalia, J., dissenting).

${ }^{15}$ See John StUART Mill, On Liberty 139 (David Bromwich \& George Kateb eds., 2003).
} 
impermissible judgments about the content of the condemned's ontological commitments, and therefore fails review under the principles of Lawrencestyle metaprivacy.

Part III attempts to harmonize my reading and extension of Lawrence with the existing doctrinal and theoretical landscape. Section III.A traces the evolution of metaprivacy within the tort privacy, Fourth Amendment privacy, and fundamental decision privacy cases, and relates metaprivacy to the doctrine on government regulation of hate speech and hate crimes. Section III.B situates metaprivacy within the academic literature on privacy. I ultimately argue that refusing to read into the doctrine a distinction between homosexual conduct and certain other forms of a priori criminal conduct is consistent with a shift in our understanding of liberty towards a government of presumptively limited powers.

A footnote is in order before I proceed. By taking seriously the language Justice Kennedy uses in Lawrence, this paper engages in a selfconscious act of what Roberto Mangabeira Unger has termed, with considerable distress, "rationalizing legal analysis." 16 Rationalizing legal analysis is the translation of "law prospectively made as the product of conflicting wills and imaginations, interests and ideals," into "law retrospectively represented as the expression of connected policies and principles." 17 It is turning one's head at jurisprudence as socio-political compromise, and pretending that it is grounded in reason. A convincing realist reading of Lawrence is plainly available. Lawrence appears to be but the most high-profile installment in a jurisprudence of homosexuality that arose in the years following Bowers. Without an alternative theory of the case, ${ }^{18}$ the many voices in sympathy with the result the Romer majority reached could not help but find Justice Scalia's bitter dissent a touch disquieting. If homosexual status was not subject to heightened scrutiny, and indeed if homosexual conduct could be criminalized, how could a law forbidding gays from acquiring anti-discrimination legislation be unconstitutional? Would it also be unconstitutional to forbid legislation that excludes convicted felons from anti-discrimination legislation? But one explanation of Romer, Lawrence and, more recently, Limon v. Kansas, ${ }^{19}$ is that, whatever the rhetoric of those decisions, a person who desires physical

\footnotetext{
${ }^{16}$ Roberto Mangabeira Unger, What Should Legal Analysis Become? 36 (1996).

${ }^{17} I d$. at 69 .

${ }^{18}$ See, e.g., Akhil Reed Amar, Attainder and Amendment 2: Romer's Rightness, 95 MiCH. L. REV. 203 (1996) (suggesting that Colorado's Amendment 2 violated the Bill of Attainder Clause of Article I, § 10)

${ }^{19} 539$ U.S. 955 (2003). In Limon, the Court remanded to the Court of Appeals of Kansas a case in which that court had upheld a statutory rape law that applied a greater penalty to same-sex rapists. See State v. Limon, 41 P.3d 303 (Kan. Ct. App. 2002).
} 
and emotional intimacy with a same-sex partner simply is treated differently under the Constitution than a person who desires other socially disfavored conduct. On this view, Romer does for gays what City of Cleburne v. Cleburne Living Center ${ }^{20}$ did for retarded persons: it extends to them the courtesy of heightened scrutiny without quite saying so.

I do not doubt that, at least in "hard cases," 21 jurisprudence is forged in the manner just described, nor do I doubt that cases raising the constitutionality of capital punishment sentencing schemes or laws against homosexual sodomy qualify as "hard cases." But this paper is less interested in what the Justices were doing than in what they were saying. Romer, Lawrence, and Limon could be limited to their facts, but they would not then qualify as jurisprudence under our doctrinal fictions. ${ }^{22} \mathrm{I}$ am less interested in reaching a firm conclusion than in broadening the terms of doctrinal debate by challenging the Court to articulate a non-arbitrary reason why particular a priori criminal conduct-sodomy-receives unique judicial protection. If the reader and I end this conversation disagreeing only on the proper place of legal formalism in American constitutional discourse, then I consider it a victory for the argument.

Rationalizing legal analysis holds that "[t]he voice of reason must speak, although belatedly, in history, redescribing and reorienting the historical mess." ${ }^{23}$ Though concededly messy, the privacy jurisprudence, if it is to earn the title, must either be willing to recognize gays as having distinct interests worthy of special protection just like other identity-based groups, or it needs to examine whether the content of one's character has any legal significance. Otherwise, principle and logic will indeed "have nothing to do with the decisions of this Court."24

\section{LAWRENCE V. TEXAS AND METAPRIVACY}

In September, 1998, officers of the Harris County Police Department entered a private residence in the Houston area to investigate a report of an armed intruder breaking into a home. ${ }^{25}$ Upon entering the home, the officers

${ }^{20} 473$ U.S. 432 (1985).

${ }^{21}$ I borrow here from Ronald Dworkin. See RonALD DwORKIN, TAKING RIGHTS SERIOUSLY 81 (1977).

${ }^{22}$ See Henry M. Hart, JR. \& Albert M. SACKS, The Legal Process 666 (1958) (writing that "adjudication is meaningless unless the decision is reached by some rational process . . . [and] if a decision is to be rational it must be based upon some rule, principle or standard").

${ }^{23}$ UNGER, supra note 16 , at 68.

${ }^{24}$ Lawrence, 539 U.S. at 605 (Scalia, J., dissenting).

${ }^{25}$ See Associated Press, Activists See Case as Test of Texas Sodomy Law, CHI. TRIB., Nov. 7, 1998, at 5. The report turned out to be false. Id. 
witnessed John Geddes Lawrence and Tyron Garner engaged in anal sex. The two men were arrested, charged, and convicted of violating Section 21.06(a) of the Texas Penal Code, which prohibited "deviate sexual intercourse" with someone of the same sex. ${ }^{26}$ The case on appeal concerned the constitutionality of the statute under the Fourteenth Amendment. Lawrence's immediate holding was that Texas's prohibition on same-sex sodomy violated the Due Process Clause, and that Bowers v. Hardwick was wrong, both in methodology and in outcome, the day it was decided. ${ }^{27}$

Lawrence is otherwise famously obtuse. An extraordinary number of commentators have weighed in on its holding and we must, as always, look forward to future cases to vindicate this account or that one. But a lawyer's job is to harmonize evidence, and Lawrence leaves many clues as to its holding, clues that provide substantial fodder for discourse even at this relatively early stage in its precedential life. This Part defends one reading of Lawrence, namely that the case raises a bar to morals-based regulation of conduct recognized by social consensus as self-defining. Along the way, I demonstrate how this reading is related to but distinct from three alternative views: first, that the case instantiates a broad form of John Stuart Mill's harm principle; second, that it is fundamentally a case about desuetude; and third, that it forms a part of what William Eskridge describes as a "jurisprudence of tolerance." 28

\section{A. Lawrence as On Liberty}

Reading into Lawrence John Stuart Mill's harm principle - the idea that "the only purpose for which power can be rightfully exercised over any member of a civilized community, against his will, is to prevent harm to others" ${ }^{29}$ - is tantalizing, and Justice Kennedy does not do enough to discourage it. Lawrence does not, after all, call itself a privacy case. The opinion mentions the right of "privacy" only in stating the questions presented for certiorari and in recapping the Court's holding in Griswold v.

\footnotetext{
${ }^{26}$ Tex. Penal Code AnN. § 21.06(a) (Vernon 2003). The Texas Penal Code defined "deviate sexual intercourse" as "(A) any contact between any part of the genitals of one person and the mouth or anus of another person; or (B) the penetration of the genitals or the anus of another person with an object." Id. § 21.01(1).

${ }^{27}$ Lawrence, 539 U.S. at 576-78.

${ }^{28}$ William N. Eskridge, Jr., Lawrence's Jurisprudence of Tolerance: Judicial Review to Lower the Stakes of Identity Politics, 88 MinN. L. REV. 1021 (2004).

${ }^{29}$ MILL, supra note 15 , at 80.
} 


\section{Beyond Lawrence: Metaprivacy and Punishment}

Connecticut, ${ }^{30}$ whereas it mentions "liberty" upwards of twenty-five times. ${ }^{31}$ The opinion makes its emphasis clear from the opening paragraph:

Liberty protects the person from unwarranted government intrusions into a dwelling or other private places. In our tradition the State is not omnipresent in the home. And there are other spheres of our lives and existence, outside the home, where the State should not be a dominant presence. Freedom extends beyond spatial bounds. Liberty presumes an autonomy of self that includes freedom of thought, belief, expression, and certain intimate conduct. The instant case involves liberty of the person both in its spatial and more transcendent dimensions. ${ }^{32}$

This passage could be the prologue to Mr. Herbert Spencer's Social Statics, ${ }^{33}$ and it is far from the opinion's only grist for libertarian spin. Justice Kennedy writes that the Court's ruling, "as a general rule, should counsel against attempts by the State, or a court, to define the meaning of the relationship or to set its boundaries absent injury to a person or abuse of an institution the law protects. $"{ }^{34}$ In attempting to define, as it has to, what is meant by "injury," 35 the Court makes clear that morals offenses will not suffice. Justice Kennedy writes explicitly that Justice Stevens's Bowers dissent, in particular the hardly obvious assertion that "the fact that the governing majority in a State has traditionally viewed a particular practice as immoral is not a sufficient reason for upholding a law prohibiting the practice . . . ., ${ }^{36}$ controls the analysis in Lawrence. Finally, the six-Justice majority reaffirmed the statement made by a three-judge plurality in Planned Parenthood v. Casey, that the Court's "obligation is to define the liberty of all, not to mandate our own moral code." 37 This view carries strong echoes of the neo-Millian philosophy of H.L.A. Hart, who believed

${ }^{30}$ See Lawrence, 539 U.S. at 564-65 (discussing 381 U.S. 479 (1965)).

${ }^{31}$ See Randy E. Barnett, Justice Kennedy's Libertarian Revolution: Lawrence v. Texas, in CATO Supreme Court REVIEW, 2002-2003, at 21, 34 (James L. Swanson ed., 2003)

${ }^{32} I d$. at 562.

${ }^{33}$ Cf. Lochner v. New York, 198 U.S. 45, 75 (Holmes, J., dissenting) ("The Fourteenth Amendment does not enact Mr. Herbert Spencer's Social Statics.”).

${ }^{34} \mathrm{Id}$. at 567.

${ }^{35}$ Mill never defined "harm" with any satisfaction. Living as we do within social space, virtually every action we take intrudes in some way upon the interests of others. See note 338, infra, and accompanying text.

${ }^{36}$ Id. at 577 (quoting Bowers v. Hardwick, 478 U.S. 186, 216 (1986) (Stevens, J., dissenting)).

${ }^{37}$ Id. at 571 (quoting Planned Parenthood v. Casey, 505 U.S. 833, 850 (!992)). 
that even prostitution could not be regulated so long as it occurred outside of public view. ${ }^{38}$

While some commentators have taken the "harm principle" bait, ${ }^{39}$ others have kept the wax of constitutional pragmatism firmly in their ears. ${ }^{40}$ Perhaps the best evidence that Justice Kennedy's principle is neither Mill's nor Hart's is that he more or less tells us as much. He explains in dicta that the case "does not involve ... prostitution," implying thereby that it would be a different case if it did. ${ }^{41}$ Although one can imagine theoretical grounds for distinguishing anti-prostitution from anti-sodomy laws - based, for example, on implied coercion or regulation of commerce-these distinctions are not unimpeachable. Certainly not all commercial sex exchanges are coercive, and refusing to allow individuals to engage in a particular form of commerce because it is viewed as immoral runs only slightly less directly afoul of a Millian reading of Lawrence than the Texas anti-sodomy regulation. Moreover, Justice Kennedy conspicuously segregates his mention of prostitution from his earlier mention of "persons who might be injured or coerced or who are situated in relationships where consent might not easily be refused." ${ }^{42}$ It is difficult to avoid the conclusion that anti-prostitution laws still survive scrutiny not on some consent-based theory but because prostitution is traditionally viewed as immoral.

Similarly, Justice Kennedy in two places appears determined to remove same-sex marriage from the scope of Lawrence's holding. First, he exempts from the case's purview, as mentioned above, "abuse of an institution the law protects." 43 Second, he disclaims having announced that "the government must give formal recognition to any relationship that homosexual persons seek to enter." 44 What beyond an explicitly moral judgment, Laurence Tribe asks, "could be the rationale for permitting an otherwise eligible same-sex couple to enjoy the tangible benefits and assume the legal obligations of some version of civil union but withholding from them that final measure of respect— that whole that plainly exceeds

\footnotetext{
${ }^{38}$ H.L.A. HART, LAW, LIBERTY AND MORALITY 13 (1963).

${ }^{39}$ See, e.g., Barnett, supra note 31, at 21; Richard A. Epstein, Of Same-Sex Relationships and Affirmative Action: The Covert Libertarianism of the United States Supreme Court, 12 S. CT. ECON. REV. 75 (2004); Paul M. Secunda, Lawrence's Quintessential Millian Moment and Its Impact on the Doctrine of Unconstitutional Conditions, 50 VILL. L. REV. 117 (2005).

${ }^{40}$ See, e.g., Dale Carpenter, Is Lawrence Libertarian?, 88 MinN. L. REV. 1140 (2004); Miranda Oshige McGowan, From Outlaws to Ingroup: Romer, Lawrence, and the Inevitable Normativity of Group Recognition, 88 MinN. L. REV. 1312 (2004). But see Randy E. Barnett, Grading Justice Kennedy: A Reply to Professor Carpenter, 89 MinN. L. REV. 1500 (2005).

${ }^{41}$ Lawrence, 539 U.S. at 578.

${ }^{42} I d$. The second clause is an obvious reference to incest.

${ }^{43} \mathrm{Id}$. at 567.

${ }^{44}$ Id. at 578 .
} 
the mere sum of its component legal parts?" ${ }^{\prime 45}$ It is not for a Court, in dicta, to limit the prospective scope of its holdings. ${ }^{46}$ But a Court's attempts to do so do speak directly to the principle it is presumptively announcing, and Justice Kennedy's various proscriptions and disclaimers do not seem consistent with a broad harm principle.

We can expand our examination of prospective applications beyond what is express, and hypothesize responses to other morals legislation, including the remainder of Justice Scalia's laundry list of state laws he believes threatened by the majority's holding. Faced with his imagined challenges to laws against bigamy, bestiality, and obscenity, ${ }^{47}$ or, say, drug use, kidney sales, suicide, or slave wages, ${ }^{48}$ among others, the passive virtues exhort us to seek within Lawrence's text a more jurispathic limiting agent than a simple harm principle. ${ }^{49}$ Justice Kennedy writes that "adults may choose to enter upon [a homosexual] relationship in the confines of their homes and their own private lives and still retain their dignity as free persons, ${ }^{, 50}$ and so perhaps the correct limiting principle is that consensual conduct will be protected when it occurs within the home. Such a principle does not seem well-tailored to the text of the opinion, however, as it would appear to protect incest and prostitution and yet would be deeply inconsistent with the majority's apparently self-conscious shift away from the word "privacy." "There are other spheres of our lives and existence, outside the home," the Court tells us, "where the State should not be a dominant presence. Freedom extends beyond spatial bounds." ${ }^{, 51}$ Thus, while Lawrence's libertarian overtures are too brazen to be countenanced fully, they are also too brazen to be ignored. The opinion clearly means to disfavor certain species of morals legislation. The trick is to figure out what is so special about anti-sodomy laws. As I explain below, the permissibility

${ }^{45}$ Laurence H. Tribe, Lawrence v. Texas: The "Fundamental Right" That Dare Not Speak Its Name, 117 HARV. L. REV. 1893, 1946 (2004); see also Lawrence, 539 U.S. at 601 (Scalia, J., dissenting) (“" $[\mathrm{P}]$ reserving the traditional institution of marriage' is just a kinder way of describing the State's moral disapproval of same-sex couples.") (quoting Lawrence, 539 U.S. at 585 (O'Connor, J., concurring in the judgment)).

${ }^{46}$ See id. at 605 ("This case 'does not involve' the issue of homosexual marriage only if one entertains the belief that principle and logic have nothing to do with the decisions of this Court."). ${ }^{47} \mathrm{Id}$. at 590.

${ }^{48}$ Randy Barnett argues that Lawrence in fact opens the door to challenges to economic regulation, and properly so. See Barnett, supra note 31, at 21. But see Carpenter, supra note 40, at 1152 ("A Court about to embark on a new and highly controversial adventure into judicially mandated laissez-faire economics would at least drop a hint.").

${ }^{49}$ As Justice White wrote in Bowers, "The law is constantly based on notions of morality, and if all laws representing essentially moral choices are to be invalidated under the Due Process Clause, the courts will be very busy indeed." Bowers v. Hardwick, 478 U.S. 186, 196 (1986).

${ }^{50}$ Lawrence, 539 U.S. at 567, 575.

${ }^{51} I d$. at 562 . 
of the legislation depends not on the nature of the interests being protected - for example, community morals versus physical victimizationbut on the nature of the interests being infringed.

\section{B. Lawrence as Metaprivacy}

The principle Lawrence announces is both more timid and bolder than a simple harm principle. It does not reach the full panoply of morals regulation, but failing to do so grants it the jurisprudential space to be arguably more protective of particular facets of individual liberty than even Mill. In the eyes of the Lawrence majority, laws regulating the private sexual conduct of homosexuals do not simply infringe on their right to privacy, the way a law against viewing pornography in the home might, ${ }^{52}$ or on their right to liberty, the way a law against public nudity might. ${ }^{53}$ Rather, the Court held that such regulations effect a dignitary harm. Justice Kennedy uses the word "demean" in three places in the opinion. First, he writes, "To say that the issue in Bowers was simply the right to engage in certain sexual conduct demeans the claim the individual put forward, just as it would demean a married couple were it to be said marriage is simply about the right to have sexual intercourse." ${ }^{, 54}$ Second, he writes that Bowers' very "continuance as precedent demeans the lives of homosexual persons." 55 Finally, he writes that the State "cannot demean [petitioners'] existence or control their destiny by making their private sexual conduct a crime. ${ }^{56}$

The comparison to marriage should help illuminate how it is that defining the right simply as a right to engage in sexual intercourse is not just misleading but is in fact a dignitary insult. Justice Kennedy's allusion to marriage refers directly to Griswold, in which the Court struck down Connecticut's anti-birth control laws. ${ }^{57}$ In that case, Justice Douglas wrote in sweeping terms for the majority that marriage "is an association that promotes a way of life, not causes; a harmony in living, not political faiths; a bilateral loyalty, not commercial or social projects." ${ }^{.58}$ Physical intimacy in marriage is no mere vulgar satisfaction of prurient interests, but rather stands in for a transcendent, merged identity. Marriage is a redefinition of

\footnotetext{
${ }^{52}$ See Stanley v. Georgia, 394 U.S. 557 (1969).

${ }^{53}$ See Lawrence, 539 U.S. at 601 (Scalia, J., dissenting).

${ }^{54} \mathrm{Id}$. at 567.

${ }^{55} \mathrm{Id}$. at 575 .

${ }^{56} \mathrm{Id}$. at 578 .

${ }^{57} 381$ U.S. 479 (1965), cited in Lawrence, 539 U.S. at 564-65.

${ }^{58}$ Id. at 486.
} 
personhood, of which the freedom to engage in sexual intercourse-with or without birth control - is but one element. Similarly, the freedom to engage in sexual intercourse within a homosexual relationship helps constitute a manifestation of gay personhood; it is a form of self-identification. ${ }^{59}$ Thus it is that criminalization of homosexual conduct both demeans the lives of homosexuals and controls their destiny. The connection to Casey, which Justice Kennedy cites repeatedly, is readily apparent, for outlawing abortion similarly threatens to control an individual's destiny, that of the would-be mother. He writes, quoting Casey, that a homosexual person, as much as a heterosexual, "may seek autonomy" for the purpose of "defin[ing] the attributes of personhood" by "defin[ing] one's own concept of existence, of meaning, of the universe, and of the mystery of human life." $" 60$

The crucial rhetorical move is the presumption that private sex acts are elemental to the self-definition of gays. Justice Scalia makes much in his dissent in Romer v. Evans of the lack of a meaningful distinction between homosexual "orientation" and homosexual "conduct." remained good law, it was useful for someone urging the constitutionality of laws disfavoring gays to collapse this distinction. Said Justice Scalia in Romer, "[W]here criminal sanctions are not involved, homosexual 'orientation' is an acceptable stand-in for homosexual conduct." ${ }^{\text {"62 }}$ Lawrence said, in essence, that where criminal sanctions are involved, the fact that homosexual conduct is a stand-in for homosexual orientation means antisodomy laws must fail. It is precisely because homosexual orientation may be defined by homosexual conduct that a law disfavoring the conduct is, like Romer's Amendment 2, in fact a law whose purpose is to disfavor a class of individuals. As Justice Kennedy writes, "When homosexual conduct is made criminal by the law of the State, that declaration in and of itself is an invitation to subject homosexual persons to discrimination both in the public and in the private spheres." ${ }^{\text {" }}$ The principle that we can draw from this statement is that where an individual's status is defined by conduct, the State may not outlaw that conduct on moral grounds. ${ }^{64}$ To do

\footnotetext{
${ }^{59}$ See id. at 567 ("When sexuality finds overt expression in intimate conduct with another person, the conduct can be but one element in a personal bond that is more enduring."); see also Tribe, supra note 45, at 1905-06 (arguing that even if the Texas law had applied both to same-sex acts and to opposite-sex acts, the Court would still be struck down because "sodomy" is pervasively and pejoratively associated with gays).

${ }^{60}$ Lawrence, 539 U.S. at 574.

${ }^{61}$ Romer v. Evans, 517 U.S. 620, 640-42 (Scalia, J., dissenting).

${ }^{62} I d$. at 642 .

${ }^{63}$ Lawrence, 539 U.S. at 575.

${ }^{64} C f$. Robinson v. California, 370 U.S. 660, 666 (1962) (striking down a statute for making "the 'status' of narcotic addiction a criminal offense.").
} 
so would interfere too intrusively in the life of the individual, and violate her right to privacy in its "more transcendent dimensions." 65

The reading I urge helps to explain why Justice Kennedy does not specify the level of scrutiny he is applying. On one hand, he writes that Texas's anti-sodomy statute "furthers no legitimate state interest which can justify its intrusion into the personal and private life of the individual." This formulation implies that Justice Kennedy is employing rational-basis review. On the other hand, he makes this statement immediately after quoting Casey's mandate that "[i]t is a promise of the Constitution that there is a realm of personal liberty which the government may not enter." Under our constitutional tradition, the realm of personal liberty which the government may not enter is not protected by mere rational basis review. ${ }^{68}$ Rather, the State must justify its entrance into such realms with a compelling interest, and it must tailor its means narrowly to effectuate that interest. To suggest, as Justice Kennedy does explicitly, that Lawrence follows from the Griswold line of cases is to imply that strict scrutiny applies. ${ }^{69}$ A third option, of course, is that Justice Kennedy is employing strict scrutiny but that he does not believe the statute even survives rational basis review. ${ }^{70}$ The important point, though, is that once we collapse the status-conduct distinction, it becomes unnecessary to specify a particular standard of review. In the spirit of the Bill of Attainder clauses, to make a particular class of individuals a target of the criminal law for no reason other than disapproval of their very being is illegitimate as a matter of first principles. ${ }^{71}$ Thus, on this view, even to reach a tiers of scrutiny analysis in Lawrence demeans the lives of homosexual persons.

${ }^{65}$ Lawrence, 539 U.S. at 562.

${ }^{66} \mathrm{Id}$. at 578 .

${ }^{67}$ Id. at 578 (quoting Planned Parenthood v. Casey, 505 U.S. 833, 847 (1992)).

${ }^{68}$ See generally supra text accompanying notes 272-273 (discussing the doctrinal void formed by weakening the level of scrutiny to apply to Fourth Amendment cases).

${ }^{69}$ See Cass R. Sunstein, What Did Lawrence Hold? Of Autonomy, Desuetude, Sexuality, and Marriage, 2003 SuP. CT. REV. 27, 48 ("The Court's assimilation of the Lawrence problem to that in Griswold and its successors suggests that a fundamental right was involved."); Tribe, supra note 45, at 1917 ("[T]he strictness of the Court's standard in Lawrence, however articulated, could hardly have been more obvious.").

${ }^{70}$ Justice Scalia would quarrel with this conclusion. See Lawrence, 539 U.S. at 599 (Scalia, J., dissenting) (calling the proposition that there is no rational basis for the Texas law "so out of accord with our jurisprudence - indeed, with the jurisprudence of any society we know-that it requires little discussion"). But see id. at 583 (O'Connor, J., concurring in the judgment) ("Moral disapproval of a group cannot be a legitimate governmental interest under the Equal Protection Clause....").

${ }^{71}$ See, e.g., Amar, supra note 18 (arguing that the Colorado amendment at issue in Romer could have been invalidated under the logic of the Bill of Attainder clauses). 
What is so special, then, about anti-sodomy laws is that they threaten not some undifferentiated liberty, but specifically the liberty of selfdefinition. We now can hypothesize an answer to the libertarian who extols the opinion's scant references to "privacy." Lawrence concerns not what Michael Sandel calls "old privacy"- "the interest in keeping intimate affairs from public view"- but what he calls "new privacy"- "the right to make certain sorts of choices, free of interference by the state." 72 The particular types of choices an individual has the right to make are those that qualify in some relevant way as self-defining. Given that Lawrence involved paradigmatic "old privacy" conduct, it would have confused matters to write the opinion in the language of privacy rights. To avoid similar confusion, I refer to Lawrence's particular brand of privacy as "metaprivacy," and define it as the right to engage in self-definitional conduct free from normalizing governmental interference.

\section{On Desuetude}

To this point, my argument remains underspecified. I have not yet nominated any particular catalyst for identification of conduct as selfdefinitional. Surely not all acts of self-definition are equally protected. Unless Lawrence identifies a process for defining the relevant class, it has no answer to Justice Scalia's criticism that a law against public nudity, for example, is suspect because it "targets 'the conduct that is closely correlated with being a nudist,' and hence 'is targeted at more than conduct'; it is 'directed toward nudists as a class.",73 Miranda Oshige McGowan illustrates the point by comparing Lawrence to Barnes v. Glen Theatre, in which a Court plurality held that an Indiana statute that required strippers to wear pasties and g-strings in adult-only clubs "furthers a substantial government interest in protecting order and morality." 74 Unless Lawrence overrules Barnes, it must explain, as McGowan puts it, "why [t]he liberties of nude dancers and strip club goers [don't] count, and the liberties of gays do." The answer McGowan settles on is that "gays as a set are a group while the set of nude dancers and people who go to strip clubs are not a group." ${ }^{, 75}$ She writes that in distinguishing between simple

\footnotetext{
${ }^{72}$ Michael J. Sandel, Moral Argument and Liberal Toleration: Abortion and Homosexuality, 77 CAL. L. REV. 521, 526, 528 (1989).

${ }^{73}$ Lawrence, 539 U.S. at 601 (Scalia, J., dissenting).

${ }^{74}$ McGowan, supra note 40, at 1326 (citing 501 U.S. 561, 569 (1991)).

${ }^{75}$ Id. at 1329.
} 


\section{Beyond Lawrence: Metaprivacy and Punishment}

classifications and relevant groups, "the Court's practice is essentially normative." ${ }^{, 76}$

This paper's project is to not give up quite so easily. I wish to take seriously the Justices' contention that the distinctions drawn in Lawrence are neither ad hoc judgments nor naked manifestations of their own moral codes. In fact, the opinion provides generous support for just the opposite. The Court spends substantial ink on the idea that the crucial moving part in defining the scope of the Due Process Clause is not the composition of the Court but rather social convention. Justice Kennedy rejects the backwardlooking amateur historiography of the Bowers majority in favor of his own sideways-looking amateur sociology. "In all events," he writes, "we think that our laws and traditions in the past half century are of most relevance here. These references show an emerging awareness that liberty gives substantial protection to adult persons in deciding how to conduct their private lives in matters pertaining to sex." $" 77$ The references Justice Kennedy cites include changes in the Model Penal Code and state statutes, the decision of the European Court of Human Rights in Dudgeon v. United Kingdom, ${ }^{78}$ and, perhaps most significantly, the fact that sodomy statutes had been systematically unenforced. ${ }^{79}$

Cass Sunstein, acknowledging the importance of this language, concludes that Lawrence is an application of the common law principle of desuetude.$^{80}$ The idea at play in Lawrence, Sunstein suggests, is that "at least in some circumstances, involving certain kinds of human interests, a criminal law cannot be enforced if it has lost public support." ${ }^{\prime 1}$ The justification for desuetude is that statutes that remain on the books but are not generally enforced invite arbitrary, discriminatory, and undemocratic prosecutions. ${ }^{82}$ The individual interest at stake in Lawrence was thereby converted from a simple interest in sexual autonomy to an interest in avoiding victimization by arbitrary exercises of public power. This reading of Lawrence, Sunstein notes, "mutes the apparent roots of Lawrence in substantive due process. The idea of desuetude is, in a sense, a procedural

\footnotetext{
${ }^{76} \mathrm{Id}$. at 1334 .

${ }^{77}$ Lawrence, 539 U.S. at 571-72 (emphasis added).

7845 Eur. Ct. H.R. (ser. A) (1981) (holding that Northern Ireland's anti-sodomy law violated Article 8 of the European Convention on Human Rights).

${ }^{79}$ Id. at $572-73$.

${ }^{80}$ See Sunstein, supra note 69 , at 30.

${ }^{81} \mathrm{Id}$.

${ }^{82}$ Id. at 50; see also AlEXANDER M. BiCKEL, THE LEAST DANGERous BrANCH 152 (1962) ("When [an unenforced statute] is resurrected and enforced, it represents the ad hoc decision of the prosecutor, and then of the judge and jury, unrelated to anything that may realistically be taken as present legislative policy.").
} 
one." ${ }^{83}$ Since the issue is primarily one of "notice," the Lawrence Court extended beyond simply responding to social fact to "requiring an evolution in public opinion-something like a broad consensus that the practice at issue should not be punished." ${ }^{\prime 4}$

Sunstein criticizes the libertarian reading of Lawrence-what he calls the "simple autonomy" reading-for insufficiently taking account of the role social consensus plays in the opinion. ${ }^{85}$ But the desuetude reading might similarly be criticized as insufficiently responsive to the remainder of the opinion. Sunstein essentially concedes as much. Referring to the "narrow" version of his thesis, that "the state may not rely on a justification [for a criminal statute] that has lost public support," ${ }^{, 86}$ Sunstein writes that "for it to operate, we must have an antecedent way, to some extent independent of public convictions, to determine whether an interest has some kind of constitutional status." ${ }^{87}$ Social consensus, that is, is not in itself sufficient to cabin Lawrence's holding within workable limits. Neither, I argue above, is the principle of self-definitional conduct. The best way to understand the roles of social consensus and of self-definitional conduct, however, is in combination.

\section{On Social Consensus}

Social consensus plays a crucial role in delimiting the contours of the right the Court seeks to protect. It may operate in Lawrence-and presumably in other privacy cases - in one of at least two ways. First, it may function literally as Justice Kennedy suggests: an emerging awareness that a particular practice forms part of the liberty protected by the Due Process Clause incorporates that practice into the canon of fundamental freedoms. One is reminded here of Justice Handy's views on the central role public opinion should play in the fate of the Speluncean Explorers. ${ }^{88}$ While this tautological approach to constitutional decisionmaking is perfectly sensible for a legal realist like Justice Handy, it will not satisfy the doctrinalist, ceaselessly concerned that "legislative policy making [b]e distinguished from judicial rule applying." $" 89$ The role of a judge is to apply law, such as the Due Process Clause, to relevant facts, such as the presence

\footnotetext{
${ }^{83}$ Sunstein, supra note 69 , at 50.

${ }^{84} \mathrm{Id}$. at 49 (emphasis added).

${ }^{85} \mathrm{Id}$.

${ }^{86} I d$. at 51 .

${ }^{87} I d$. Sunstein does not resolve this difficulty.

${ }^{88}$ See Lon L. Fuller, The Case of the Speluncean Explorers, 62 HARV. L. REV. 616, 637-44 (1949).

${ }^{89}$ Philip BobBitt, Constitutional FAte 41 (1982).
} 
of a particular social consensus. This approach converts fact into law by allowing social consensus to supplant the judge as decisionmaker.

Social consensus is not, however, incapable of playing a part in principled constitutional decisionmaking. Consider the following alternative to the approach just discussed: The relevant social consensus is not that homosexual sodomy is protected by the Due Process Clause but that homosexual sodomy is definitional-as opposed to merely incidentalconduct for certain members of the political community. It is true that reasonable people may differ as to whether "gay person" describes an "identity" in precisely the same way as, say, "nudist" does, but Lawrence might plausibly be read as a judicial announcement of public recognition of the former identity but not the latter. Nudism, that is, is not (yet?) recognized as an "attribute of personhood." Rather, like "juggler," "jogger," or "strip club goer," it is viewed, rightly or wrongly, as a recreational choice incidental to self-definition. The advantage of this approach over the Justice Handy approach is that its rule of decision is not the fact of social consensus, but the legal principle that self-definitional conduct forms part of the liberty protected by the Due Process Clause. What doctrine asks of its principles is that they define with consistency the contours of the relevant legal debate. The first approach, awarding due process protection to conduct that social consensus recognizes as deserving due process protection, generates no criteria for debate. The second approach allows lawyers, judges, and academics to engage in Socratic dialogue over whether "self-definitional conduct," however defined, is sufficiently important or coherent to warrant incorporation into substantive due process.

Taking seriously this narrow role for social consensus, Justice Scalia's list of threatened morals laws begins to diminish. ${ }^{90}$ There is hardly an identifiable social consensus that masturbators or those who have sex with animals are, like gays, a class of individuals whose life choices are not merely "deviant" incidents of their personalities, but in fact constitutive of their personhood, ${ }^{91}$ and prostitution is commonly thought of as a labor not of love, but of necessity. Bigamy and same-sex marriage are more difficult to distinguish. As I have discussed, marriage earns its status as a fundamental right under our jurisprudence precisely because it is "an association that promotes a way of life." ${ }^{.92}$ Not only is marriage almost explicitly excluded from Lawrence's sweep, however, but it is problematic

${ }^{90}$ See Lawrence v. Texas, 539 U.S. 558, 590 (2003) (Scalia, J., dissenting).

${ }^{91}$ Moreover, as Sunstein observes, there are no laws against masturbation. Sunstein, supra note 69 , at 49 .

${ }_{92}$ Griswold v. Connecticut, 381 U.S. 479, 486 (1965) (emphasis added); see notes 57-59, infra, and accompanying text. 
to refer to bans on certain types of marriages as "punishment." Lawrence does not demand (as resort to the Equal Protection Clause might) that the State not discriminate against gays at all, only that it not use its coercive power to criminalize their identities. Although criminal sanctions for particular cohabitational choices, say, may indeed raise Lawrence problems, refusing to extend formal state recognition to particular social arrangements is hardly analogous.

\section{On the Politics of Recognition}

Another way to understand the meaning of this new metaprivacy is in terms of William Eskridge's taxonomy of identity-based social movements. ${ }^{93}$ Eskridge describes three stages of such movements. At stage 1, a minority group "challenges consensus that its distinguishing trait (color, sex, sexuality) is a malignant variation from the norm." At stage 2, society "revises consensus to allow that the minority trait is a tolerable variation, but not as good as the norm." Finally, in stage 3, society again "revises consensus to recognize that the minority trait is a benign variation and that there is no single norm." 94 On my reading, Justice Kennedy's opinion is best read as moving gays from stage 0 to stage 1 , that is, from not being a constitutionally recognized identity group at all to being one whose standing as a member of the polity is recognized. As Justice Scalia argues vociferously in Romer, ${ }^{95}$ this recognition is a precondition to the (John Hart) Elysian protection of gay political representation that Amendment 2 threatened, and that race-based and sex-based minority groups unquestionably enjoy. ${ }^{96}$

Eskridge himself would contest the above characterization of the opinion. Calling the post-Lawrence landscape "nothing less than, but also nothing more than, a jurisprudence of tolerance," phase shift that Romer and Lawrence represent for gays is analogous to the shift that Brown v. Board of Education ${ }^{98}$ and Loving v. Virginia ${ }^{99}$

93 See William N. Eskridge, Jr., Some Effects of Identity-Based Social Movements on Constitutional Law in the Twentieth Century, 100 MicH. L. REV. 2062, 2065 (2002).

${ }^{94}$ William N. Eskridge, Jr., Pluralism and Distrust: How Courts Can Support Democracy by Lowering the Stakes of Politics, 114 YALE L.J. (forthcoming May 2005) (manuscript at 14, on file with author).

${ }^{95}$ Romer, 517 U.S. at 640-41.

${ }^{96}$ See Eskridge, supra note 28, at 1077 (discussing the value of "assur[ing] each clashing group an opportunity to persuade the community of it normative agenda").

${ }^{97}$ Eskridge, supra note 28, at 1025.

${ }^{98} 347$ U.S. 483 (1954).

${ }^{99} 388$ U.S. 1 (1967). 
represented for blacks, and that Roe v. Wade $e^{100}$ and Craig v. Boren ${ }^{101}$ represented for women. ${ }^{102}$ In practice this means that the Court has reached stage 2, wherein it "accepts the norm that sexual variation is tolerable as a matter of fact and ought to be treated as presumptively irrelevant as a matter of law." 103 In my view, Eskridge overstates the Court's solicitude of gay claims in Romer and Lawrence. I think it significant that the Court refused to accept an express invitation to elevate sexual orientation to a suspect classification and therefore explicitly to apply heightened scrutiny to regulations that discriminate against gays. ${ }^{104}$ The Court's unwillingness even to confront the appropriate level of scrutiny at least undermines the claim that the particularized dignity of gays was the majority's central animating concern. ${ }^{105}$ Rather, I argue, the Court was using gay rights cases to reinforce first principles of representative government, that conduct rather than status must be the subject of criminal law. In any event, my differences with Eskridge on this score may be largely semantic. I agree with his bottom line, that "traditionalists can no longer deploy the state to hurt gay people or render them presumptive criminals, but room remains for the state to signal the majority's preference for heterosexuality, marriage, and traditional family values."106

Deeper are my differences with Eskridge on the role of social consensus. A key feature of his "politics of recognition" is the role of the gay rights movement itself in forcing the Court's hand. Because Eskridge's is a story of how constitutional change occurs on the ground, it is vital to his account that the discriminated-against group so characterize itself, and that it advance a political agenda. Writes Eskridge, "The key to understanding Lawrence - and all its doctrinal complexities - is the Supreme Court's recognition that American democratic pluralism must

\footnotetext{
100410 U.S. 113 (1973).

101429 U.S. 190 (1976)

${ }^{102}$ Eskridge, supra note 28, at 1040; see also McGowan, supra note 40, at 1332-34 (arguing that Lawrence fits into Eskridge's schemata).

${ }^{103} I d$.

${ }^{104}$ Justice O'Connor would strike down the Texas sodomy law under the Equal Protection Clause, but because in her view it failed rational basis review. See Lawrence, 539 U.S. at 579 (O'Connor, J., concurring in the judgment). Laurence Tribe calls the Equal Protection route a "dead end," arguing that relying on the Clause would have been inadequate to the task of protecting the dignity of gays. Tribe, supra note 45, at 1907-16. Tribe, however, implicitly accepts Justice O'Connor's rational basis standard of review. See id. Justice Kennedy defends his recourse to the Due Process Clause by saying that reliance on the Equal Protection Clause would leave open the question of whether a gender-neutral statute would be constitutional. Lawrence, 539 U.S. at 575.

${ }^{105}$ But see Pamela S. Karlan, Loving Lawrence, 102 Mich. L. REV. 1447 (2004) (arguing that gay rights cases are making tiers-of-scrutiny analysis anachronistic).

${ }^{106}$ Eskridge, supra note 28, at 1025.
} 
meet the lesbian, gay, bisexual, and transgendered (LGBT) rights movement at least halfway." 107

For Eskridge, then, the self-definition of the group itself necessarily motivates the social consensus. Although it is difficult to dispute that only a sufficiently robust movement can generate the political conditions necessary for the kinds of regime shifts with which Eskridge is concerned, there is no indication within the Lawrence majority opinion itself that such agitation forms part of the doctrinal test. Lawrence, that is, does not source its emerging awareness within the gay rights movement. Social consensus as employed in Lawrence is not necessarily operationalized by recognizing a movement, but rather by recognizing an individual's claims to autonomy. ${ }^{108}$

The Bowers majority issued a challenge to those who would extend fundamental decision privacy to homosexual sodomy: "No connection between family, marriage, or procreation on the one hand and homosexual activity on the other has been demonstrated, either by the Court of Appeals or by respondent." 109 Lawrence attempts to answer the challenge by settling on control of one's metaphysical destiny. Where conduct is elemental to self-definition, the State may not criminalize that conduct based on moral approbation. Lawrence did not, then, "decree[] the end of all morals legislation." 110 It did, however, enunciate a principle susceptible to extrapolation beyond the four walls of the bedroom. This is, depending on one's perspective, either heartening or dangerous territory.

\section{Metaprivacy \& CRIMINAl SEnTEnceS}

Lawrence is, of course, a case about punishment, but most commentary on its import focuses on the threshold question of which rationales, if any, justify using the criminal law to regulate "primary" conduct. ${ }^{111}$ This Part argues that the conclusions reached apply equally to the question of which rationales justify incremental punishment. Section III.A discusses the

${ }^{107} I d$. at 1025 .

${ }^{108}$ Given that the encounter in Lawrence was a one-night stand, see Tribe, supra note 45, at 1904, emphasizing his responsiveness to the gay rights movement also would have won Kennedy neither rhetorical nor political points.

${ }^{109}$ Bowers v. Hardwick, 478 U.S. 186, 191 (1986).

${ }^{110}$ Lawrence, 539 U.S. at 599 (Scalia, J., dissenting).

${ }^{111}$ I borrow my terminology from Justice Harlan. See Mackey v. United States, 401 U.S. 667, 692 (1971) (Harlan, J., concurring in part and dissenting in part). 
constitutional framework for evaluating excessive punishment. Section III.B demonstrates that this framework cannot countenance a characterbased retributive rationale for capital punishment.

\section{A. The Constitutionality of Excessive Punishment}

It is difficult to break new ground in any analysis of the Supreme Court's treatment of the constitutionality of a given punishment regime. Several fundamental ground rules seem well-established. The State faces three broad doctrinal roadblocks before it can punish. First, the State is bound by free-standing constitutional commitments that prevent it from punishing certain types of conduct. It cannot, for example, punish for ordinary speech, for thoughts, ${ }^{112}$ or for "status." ${ }^{113}$ On the narrowest reading of Lawrence, it also cannot punish an individual for engaging in consensual homosexual sodomy in the home, though I have heretofore argued for a stronger reading that, in effect, regards such punishment as itself a form of status punishment. The second obstacle from the government's perspective is procedural: It cannot convict without providing the accused with, inter alia, a speedy trial, ${ }^{114}$ access to counsel, ${ }^{115}$ the option of a trial by jury, ${ }^{116}$ and due process of law more generally. ${ }^{117}$ The "free-standing" due process requirement has been interpreted to require, for example, that a defendant be competent to stand trial, ${ }^{118}$ and that the prosecution disclose to the accused exculpatory evidence in its possession. ${ }^{119}$ The third barrier the State faces is in the penalty phase, for which the Eighth Amendment is the prime source of constitutional guidance. Its overriding instruction, to be

\footnotetext{
${ }^{112}$ See United States v. Balsys, 524 U.S. 666, 714 (1998) (Breyer, J., concurring) (writing that "the First Amendment protects against the prosecution of thought crime"); Stanley v. Georgia, 394 U.S. 557, 566 (1969) (remarking that the state "cannot constitutionally premise legislation on the desirability of controlling a person's private thoughts"). But see United States v. Gamache, 156 F.3d 1, 8 (1st Cir. 1998) (suggesting that the constitutionality of a "thought crime" prosecution may be an open question).

${ }_{113}^{113}$ See Robinson v. California, 370 U.S. 660 (1962).

${ }^{114}$ U.S. CONST. amend. VI; see Doggett v. United States, 505 U.S. 647 (1992).

115 U.S. CONST. amend. VI; see Gideon v. Wainwright, 372 U.S. 335 (1963) (establishing the right of indigent defendants to appointed counsel); see also Strickland v. Washington 466 U.S. 668 (1984) (establishing the constitutional standard for ineffective assistance).

${ }^{116}$ U.S. Const. amend. VI; see Duncan v. Louisiana, 391 U.S. 145 (1968) (incorporating the right to jury trial against the states).

${ }^{117}$ U.S. Const. amends. V, XIV; see Jerold Israel, Free-Standing Due Process and Criminal Procedure: The Supreme Court's Search for Interpretive Guidelines, 45 ST. LOUIS U. L.J. 303 (2001) (discussing the Court's use of the free-standing due process doctrine).

${ }_{118}$ Drope v. Missouri, 420 U.S. 162 (1975).

${ }^{119}$ Brady v. Maryland, 373 U.S. 83 (1963).
} 
interpreted by reference to "evolving standards of decency," 120 is that the ultimate punishment the State inflicts may not be "cruel and unusual." These evolving standards "should be informed by "objective factors to the maximum possible extent," the most "reliable" of which is state legislation. ${ }^{122}$ This much is clear.

Less clear is the Court's position on the content of "cruel and unusual." A thick exegesis of the constitutional meaning of that phrase is beyond our scope, but we will nonetheless want to know how punishments are evaluated doctrinally. To wit, the Section will discuss to what extent "excessive" punishment is constitutionally distinct from "cruel and unusual" punishment, and whether that distinction is relevant. It will then explore the potential sources of the constitutional meaning of excessive punishment.

\section{When Is Excessiveness Unconstitutional?}

In applying the Eighth Amendment, the Supreme Court maintains that it owes legislatures deference in their choice of punishments, though the degree of deference has wavered over time and between Justices. "In assessing a punishment selected by a democratically elected legislature against the constitutional measure, we presume its validity," Justice Stewart wrote nearly thirty years ago in Gregg v. Georgia. "We may not require the legislature to select the least severe penalty possible so long as the penalty selected is not cruelly inhumane or disproportionate to the crime involved. And a heavy burden rests on those who would attack the judgment of the representatives of the people." 123 Outside the context of criminal punishment, whose jurisprudence tends not to speak in such terms, Justice Stewart's Eighth Amendment reviewing standard would be viewed as a akin to a "rational basis" test. It does not require narrow tailoring; it merely asks that the punishment not be cruel or unusual, the punishment analog to "arbitrary" in the levels-of-scrutiny context. Moreover, the test Justice Stewart articulates does not, on its face, prohibit "excessive" punishment; such a prohibition would indeed require that the legislature select the least severe penalty possible.

\footnotetext{
${ }^{120}$ See Atkins v. Virginia, 536 U.S. 304, 311 (2002) (quoting Trop v. Dulles, 356 U.S. 86, 100-01 (1958)).

${ }^{121}$ U.S. CONST. amend. VIII. ("Excessive bail shall not be required, nor excessive fines imposed, nor cruel and unusual punishments inflicted.").

${ }_{122}$ Atkins, 536 U.S. at 312 (citing Harmelin v. Michigan, 501 U.S. 957, 1000 (1991)).

${ }^{123}$ Gregg v. Georgia, 428 U.S. 153, 175 (1976).
} 
The Court has since repudiated this reading, at least as applied to capital cases. In the Court's most recent high-profile death penalty case, Roper $v$. Simmons, Justice Kennedy wrote for the majority that " $[\mathrm{t}] \mathrm{he}$ Eighth Amendment guarantees individuals the right not to be subjected to excessive sanctions." 124 A ban on "all excessive punishments"125 necessarily applies a heightened standard of scrutiny, since it requires a heightened degree of proportionality between the offense and the punishment. ${ }^{126}$ It might well be argued that the standard is akin to the "strict scrutiny" standard that attends state classifications on the basis of race. ${ }^{127}$ Indeed, the Court has required an individual inquiry into the character of an offender before he is sentenced to death in order to avoid "the risk that the death penalty will be imposed in spite of factors which may call for a less severe penalty." "28 This inquiry into mitigating factors is based on the judgment in Woodson v. North Carolina that "the penalty of death is qualitatively different from a sentence of imprisonment, however long." 129

Allowing that "death is different" has cloven the Court's review of punishments into separate inquiries for ordinary imprisonment versus the death penalty. In non-capital cases, the "heightened scrutiny" that prevents excessive punishment is neutered, at best, to what Justice O'Connor has called a "'narrow proportionality principle." "130 The existence of this principle was established in Solem v. Helm, the only case in which the Supreme Court has held a prison sentence unconstitutionally lengthy, ${ }^{131}$ but it does not now command a Court majority. In Ewing v. California, which upheld California's mandatory recidivist statute, Justices Scalia and Thomas maintained that the Eighth Amendment does not contain any proportionality principle, the very idea of proportionality being inexorably linked to one particular penological theory: retribution. ${ }^{132}$ Justices Stevens, Souter, Ginsburg, and Breyer contended in dissent that the Eighth Amendment contains a basic proportionality principle even in non-capital cases that may be applied judicially by reference to all of the many

\footnotetext{
124 125 S. Ct. 1183,1190 (2005).

${ }^{125}$ Atkins, 536 U.S. at 311 n.7.

${ }^{126}$ See id. at 311 (" $[\mathrm{I}] \mathrm{t}$ is a precept of justice that punishment for crime should be graduated and apportioned to the offense.").

${ }^{127}$ See, e.g., The Supreme Court, 1986 Term: Leading Cases, 101 HARV. L. REV. 119, 168-69 (1987) (stating unequivocally that the Supreme Court applies strict scrutiny to capital punishments)

${ }^{128}$ Lockett v. Ohio, 438 U.S. 586, 605 (1978)

${ }^{129} 428$ U.S. 280, 305 (1976).

${ }^{130}$ Ewing v. California, 538 U.S. 11, 20 (2003) (plurality opinion) (quoting Harmelin v. Michigan, 501 U.S. 957, 996-97 (1991)).

${ }^{131}$ Solem v. Helm, 463 U.S. 277 (1983)

${ }^{132} \mathrm{Id}$. at 31 (Scalia, J., concurring in the judgment).
} 
justifications for punishment: "namely, deterrence, incapacitation, retribution and rehabilitation." "133 "Whatever its functional proportionality principle, Ewing upheld a sentence of twenty five years to life for stealing three golf clubs. This is not nearly the kind of heightened scrutiny mandated for capital cases in Woodson.

A full account of the relationship between metaprivacy and excessive punishment would ask whether this difference is salient because "constitutional" or because "prudential." That is, does the Court's reluctance to engage in an excessiveness inquiry in non-capital cases result from a determination that excessive prison sentences are unproblematic constitutionally, or is it rather a matter of deference to legislative judgments, a recognition that a court simply lacks the competence to determine whether a prison sentence is too long? Justice Scalia seems to imply the latter when he says that his reason for not adhering to Solem's view that the Eighth Amendment contains a proportionality principle is because he is unable to "intelligently apply it."134 To be sure, Justice Scalia makes clear that his belief that the Eighth Amendment lacks a proportionality principle is not purely prudential in Harmelin v. Michigan, in which the Court upheld against an Eighth Amendment challenge a mandatory life sentence for possession of 672 grams of cocaine. ${ }^{135}$ Still, Justice Scalia's Harmelin opinion provides a useful articulation of the prudential argument against constitutionalizing a proportionality principle in cases reviewing the lengths of prison terms: "While there are relatively clear historical guidelines and accepted practices that enable judges to determine which modes of punishment are 'cruel and unusual,' proportionality does not lend itself to such an analysis." 136 The length of a prison sentence is a continuous variable, and so the difference between one term and the next is not susceptible to controlled analysis that references agreed-upon principles. But because "[t]he penalty of death differs from all other forms of criminal punishment, not in degree but in kind," the legislative analysis that begets it is more amenable to judicial scrutiny. ${ }^{137}$

This prudential (at least) distinction between the justiciability of the length of a prison term and the "mode" of punishment checkers the Eighth Amendment jurisprudence. The first case to consider the constitutionality of a criminal statute under the Eighth Amendment was Weems v. United States, in which the Court invalidated a Philippines statute that imposed a

\footnotetext{
${ }^{133}$ See id. at 35 (Stevens, J., dissenting).

${ }^{134}$ Ewing, 538 U.S. at 31 (Scalia, J., concurring in the judgment).

${ }^{135}$ Harmelin v. Michigan, 501 U.S. 957, 985 (1991) (plurality opinion).

${ }^{136} I d$.

${ }^{137}$ Furman v. Georgia, 408 U.S. 238, 306 (1972) (Stewart, J., concurring).
} 
fifteen-year prison sentence, a $\$ 4,000$ fine and costs for the crime of falsifying a public document. ${ }^{138}$ The imprisonment in Weems was itself atypically draconian, involving "a chain at the ankle and wrist of the offender,"139 and, in the words of the statute itself, "hard and painful labor [with] no assistance whatsoever from without the institution." ${ }^{140}$ It is at least arguable that the Weems Court was concerned more with the mode of punishment than the length itself, particularly since it took pains to describe the conditions of confinement in what it called "graphic" detail. ${ }^{141}$ Similarly, a Court plurality declared in Trop v. Dulles, which overturned a statute that stripped wartime deserters of their American citizenship, ${ }^{142}$ that "[f]ines, imprisonment and even execution may be imposed depending upon the enormity of the crime, but any technique outside the bounds of these traditional penalties is constitutionally suspect." ${ }^{143}$ The Court relied explicitly on the length-mode distinction in Rummel v. Estelle, in which the Court upheld a Texas recidivist statute. ${ }^{144}$ Then-Justice Rehnquist wrote that, unlike "unique" punishments such as the Weems statute and the death penalty, "the length of the sentence actually imposed is purely a matter of legislative prerogative." $" 145$

This paper need not take a position on the historical debate over the original understanding of the relationship between the Eighth Amendment and excessive punishment. ${ }^{146}$ Let it suffice that the doctrine expressly

\footnotetext{
${ }^{138}$ Weems v. United States. 217 U.S. 349 (1910).

${ }^{139} \mathrm{Id}$. at 366.

${ }^{140} \mathrm{Id}$. at 364

${ }^{141} I d$. at 366.

${ }^{142}$ Trop v. Dulles, 356 U.S. 86 (1958).

${ }^{143} I d$. at 100 (emphasis added).

${ }^{144}$ Rummel v. Estelle, 445 U.S. 263 (1980).

${ }^{145} I d$. at 274 (1980).

${ }^{146}$ Justice Scalia's view in Harmelin is contested. Justice Powell's majority opinion in Solem $v$. Helm found historical support in the Magna Carta, English common law, and the Bill of Rights of 1689 for the view that the Eighth Amendment prohibited excessive punishment. See Solem v. Helm, 463 U.S. 277, 284-85 (1983); see also Anthony F. Granucci, "Nor Cruel and Unusual Punishments Inflicted:” The Original Meaning, 57 CALIF. L. REV. 839 (1969) (arguing that the English Bill of Rights meant to prohibit excessive punishments). The Eighth Amendment is essentially boilerplate from the English version of one hundred years earlier. Granucci, supra, at 840. At least two additional considerations potentially weigh in favor of Justice Powell's view in Solem. First, there's the obvious structural consideration that the framers evidently thought excessive fines and excessive bail oppressive enough to constitutionalize their prohibition; it would be strange indeed if they nonetheless thought excessive punishment unobjectionable. The more sensible reading would be that a ban on excessive punishment was assumed, and that the "cruel and unusual" language was an additional qualifier. Surely it is possible for punishment to be cruel and unusual without being excessive. See LEONARD W. LEVY, ORIGINS OF THE BILL OF RIGHTS 236-37 (1999) (discussing the origins of the English Bill of Rights in the case of Titus Oates, whose whipping punishment for perjury was described as "cruel" even though floggings
} 
applies an excessiveness test to "modes" of punishment, including capital punishment, the idea being that governing principles do avail themselves. The important question for our purposes is what those principles should be.

\section{Evaluating Excessiveness}

The Roper and Atkins Courts dutifully reiterated that the sine qua non of judicial review for excessiveness under the Eighth Amendment is the "evolving standards of decency" inquiry first announced in Trop $v$. Dulles. ${ }^{147}$ Under the doctrine in capital cases, the Court is to look first at "objective indicia of consensus" that a punishment is disproportionate, and then "determine, in the exercise of [its] own independent judgment" whether there is reason to question the revealed consensus. ${ }^{148}$ This statement of the doctrine is incomplete, however. In Skinner v. Oklahoma, the Court unanimously invalidated an Oklahoma statute that provided for the sterilization of those thrice convicted of "crimes 'amounting to felonies involving moral turpitude." "149 The Skinner Court struck the statute down on Equal Protection grounds because it drew what the Court regarded as arbitrary lines between similarly situated classes of individuals, denying to one "one of the basic civil rights of man." ${ }^{, 50}$ For example, Justice Douglas wrote for the majority, "A person who enters a chicken coop and steals chickens commits a felony; and he may be sterilized if he is thrice convicted. If, however, he is a bailee of the property and fraudulently appropriates it, he is an embezzler [and therefore exempt from sterilization]." " Amendment is not the last word on the constitutionality of a particular mode of criminal punishment. ${ }^{152}$ Punishment statutes may well implicate fundamental rights other than the simple "right to life;" when they do so, those statutes are subject to heightened scrutiny. The answer to whether a

were the norm). Second, excessive punishment arguably implicates ordinary principles of due process. $C f$. Apprendi v. New Jersey, 530 U.S. 466 (2000) (applying the due process clause to sentencing enhancements). As Akhil Amar writes, "[r]ightly understood, the Constitution contains a good many provisions that are best read as declaratory and clarifying." Akhil Reed Amar, Constitutional Redundancies and Clarifying Clauses, 33 VAL. U. L. REV. 1 (1998).

${ }^{147}$ See Roper v. Simmons, 125 S. Ct. 1183,1190 (2005) (quoting Trop v. Dulles, 356 U.S. 86, 100-01 (1958)); Atkins v. Virginia, 536 U.S. 304, 311 (2002).

${ }^{148}$ Roper, 125 S. Ct. at 1192; see also Atkins, 536 U.S. at 313-16.

${ }^{149}$ Skinner v. Oklahoma, 316 U.S. 535, 536 (1942).

${ }^{150} \mathrm{Id}$. at $538-39,541$.

${ }^{151} \mathrm{Id}$. at 539. Of course, if he is an embezzler, he is also more likely to be white.

${ }^{152}$ In the post-Griswold era, Skinner has been converted into a substantive due process case. See, e.g., Washington v. Glucksberg, 521 U.S. 702, 720 (1997); Radhika Rao, Property, Privacy, and the Human Body, 80 B.U.L. REV. 359, 389 (2000) (describing Skinner as a privacy case). 
capital punishment regime is excessive, then, will be informed not only by community consensus or (potentially) the subjective views of the Justices themselves, but must answer as well to the substantive rights protected elsewhere in the Constitution.

This doctrinal qualifier, obvious perhaps but rarely stated, parallels the Court's treatment of convicts serving ordinary prison sentences. Though not always so historically, it is now axiomatic that "prisoners do not shed all constitutional rights at the prison gate." 153 The Court has repudiated decisively the view that the fact of conviction grants to the State license to punish arbitrarily. The Court has noted, for example, that the protections of the Free Exercise Clause, the Due Process Clause, and the Equal Protection Clause all apply to prisoners as well as to the general population. ${ }^{154}$ Indeed, current doctrine strongly implies that the only extra-constitutional deprivations that may be visited upon prisoners are those that "effectuate[] prison management and prisoner rehabilitative goals." 155 The typical formulation requires that prison-imposed burdens on most constitutional rights be reasonably related to "legitimate penological objectives." ${ }^{\text {"156 }}$ Being convicted of a crime naturally diminishes the convict's rights against the State, but it does so only incident to the necessities of carrying out the initial sentence.

Relatedly, the Court has stressed that the broad inquiry into aggravating and mitigating factors in the penalty phase of a capital trial cannot be so broad as to threaten independent constitutional imperatives. A state may not, for example, "characterize the display of a red flag, the expression of unpopular political views, or the request for trial by jury as an aggravating circumstance." ${ }^{\text {"157 }}$ Neither may it "attach[] the 'aggravating' label to factors that are constitutionally impermissible or totally irrelevant to the sentencing

\footnotetext{
${ }^{153}$ Sandin v. Conner, 515 U.S. 472, 485 (1995).

${ }^{154}$ Wolff v. McDonnell, 418 U.S. 539, 556 (1974); see also Cruz v. Beto, 405 U.S. 319 (1972) (per curiam) (applying the Free Exercise Clause to a Buddhist inmate).

${ }^{155}$ Sandin, 515 U.S. at 485; see Wolff, 418 U.S. at 555-56 (1974) ("There is no iron curtain drawn between the Constitution and the prisons of this country.").

${ }^{156}$ See, e.g., Thornburgh v. Abbott, 490 U.S. 401, 409 (1989) (setting the constitutional guidelines for the regulation of publications sent and received by prisoners). The Apprendi line of cases also supports a broader notion that the full range of punishment, and not merely the predicate of a given conviction, is subject to the procedural cousin of "strict scrutiny," that is, proof beyond a reasonable doubt. See Apprendi v. New Jersey, 530 U.S. 466, 476 (2000) ("Merely using the label 'sentencing enhancement' to describe [additional time imposed for a racial motive] surely does not provide a principled basis for treating [it] differently [from the underlying offense]."). But see Sherry F. Colb, Freedom from Incarceration: Why Is This Right Different from All Other Rights?, 69 N.Y.U. L. REV. 781, 816 (1994) (challenging the idea that the reasonable doubt standard can be meaningfully compared to strict scrutiny).

${ }^{157}$ Zant v. Stephens, 462 U.S. 862, 885 (1983).
} 
process, such as for example the race, religion, or political affiliation of the defendant." 158 The State's obligation to adhere to the limitations of metaprivacy is, of course, no exception. Limon v. Kansas is instructive in this regard. Recall that Limon concerned whether the State of Kansas may punish homosexual sodomy of a minor more severely than heterosexual sodomy. ${ }^{159}$ The Kansas Court of Appeals initially held that the discrepancy was permissible. ${ }^{160}$ The Kansas Supreme Court denied review, but the U.S. Supreme Court granted certiorari, reversed, and remanded in light of Lawrence. ${ }^{161}$ Although the Kansas Court of Appeals ruled on remand that the differential is justifiable, ${ }^{162}$ the Court's remand suggests that the principles of Lawrence, as with all other independent constitutional principles, informs judicial review of a sentencing enhancement.

Capital punishment is, of course, the ultimate sentencing enhancement. The death penalty, on Camus's elegant formulation, "definitively eliminates the condemned man." 163 As I have discussed, this distinguishing feature facilitates an external inquiry into whether the penalty is excessive. With respect to ordinary prison sentences, a reviewing court could not know, as a matter of elemental logic, where to begin an inquiry into excessiveness, at least not where that inquiry must be made not simply by reference to some social consensus but also by reference to fundamental principles. The only difference between a sentence of 100 months and a sentence of 105 months, after all, is five months. The remainder of this Part evaluates whether imposing capital punishment for retributive purposes is excessive by asking whether doing so vindicates constitutionally permissible values.

\section{B. Metaprivacy \& Retribution}

This Section argues that a character-based retributive rationale is constitutionally inadequate as an institutional justification for capital punishment. Two analytic moves are necessary to make out the argument, and a third is prudent to defend it. First, I must demonstrate that the retributive rationale necessarily relies on a judgment about the character of the accused. Second, I must demonstrate that this judgment is personal in a

\footnotetext{
${ }^{158} I d$.

${ }^{159}$ State v. Limon, 83 P.3d 229 (Kan. Ct. App. 2004).

${ }^{160}$ State v. Limon, 41 P.3d 303 (Kan. Ct. App. 2002) (unpublished opinion).

${ }^{161}$ Limon v. Kansas, 539 U.S. 955 (2003).

${ }^{162}$ Limon, 83 P.3d at 229. The case is presently on appeal at the Kansas Supreme Court.

163 AlBert CAmus, Reflections on the Guillotine, in Resistance, REBELLION, AND DEATH 173 , 210 (1961).
} 
constitutionally impermissible way. Finally, I will respond to a number of anticipated objections.

\section{Our Retribution Is Character-Based}

Retributive punishments, oversimplified, rely on the idea that punishment should be deserved. The obvious attraction of retribution is that it conforms nicely to our intuitions about the morality of punishment. ${ }^{164}$ Although many gradations of retributive punishment might be identified, ${ }^{165}$ retributive theories can be broadly segregated into act-based and characterbased models. An act-based model assigns moral value to particular acts, holding that "[a] person who deserves punishment deserves it because, and only because, she has performed a culpable wrongdoing." 166 By contrast, a character-based model holds that "[a] person who deserves punishment deserves it because, and only because, she has a bad moral character."

In the realm of capital punishment, the character-based theory of retribution not only is dominant but is, in a sense, constitutionally required. The overriding command of the Court's death penalty jurisprudence in the years following Gregg v. Georgia is that capital punishment must be appropriately individualized. ${ }^{168}$ Writing for a five-Justice majority in Penry

164 The retributive rationale is in the midst of a philosophical renaissance. See JAMES Q. Whitman, Harsh Justice: CRiminal PUNishment AND THE WidENING Divide BetweEN AMERICA AND EUROPE 23-24 (2003) (describing the "philosophical revival of retributivism" as "the most important Anglo-American movement of the last forty years or so"); Russell L. Christopher, Deterring Retributivism: The Injustice of "Just" Punishment, 96 Nw. L. REV. 843, 845 (2002) (calling retributivism "all the rage").

${ }^{165}$ Michael Moore's work in this area has been particularly innovative. See MiCHAEL S. MOORE, PlACING BLAME: A GENERAL THEORY OF THE CRIMINAL LAW 83-189 (1998).

${ }^{166}$ STEPHEN KERSHNAR, DESERT, RETRIBUTION, AND TORTURE 15 (2001). For examples of actbased retributive theories, see, e.g., $i d$. at 27 ("[A] bad character is neither necessary nor sufficient for deserved punishment [and] the punishment that a wrongdoer deserves [does not] track the badness of her moral character."); and ANDREW VON HIRSCH, PAST OR FUTURE CRIMES: DESERVEDNESS AND DANGEROUSNESS IN THE SENTENCING OF CRIMINALS 53 (1985) ("If the state is to carry out the authoritative response to [wrongful] conduct . . . then it should do so in a manner that testifies to the recognition that the conduct is wrong.").

${ }^{167}$ KERSHNAR, supra note 166, at 15-16. For examples of character-based theories, see, e.g., KANT, supra note 6, at 106 (arguing that only the death penalty appropriately corresponds to the 'inner wickedness' of a murderer); ROBERT NOZICK, PHILOSOPHICAL EXPLANATIONS 383 (1981) (suggesting that punishment is only appropriate for acts "attributed to a defect of character"); and Frederic R. Kellogg, From Retribution to "Desert": The Evolution of Criminal Punishment, 15 CRIMINOLOGY 179 (1977) (arguing that a report by the Committee for the Study of Incarceration reflects a concern with the individuation of punishment that finds relevant the offender's moral character).

${ }^{168}$ See, e.g., Lockett v. Ohio, 438 U.S. 586 (1978); Jurek v. Texas, 428 U.S. 262 (1976); Woodson v. North Carolina 428 U.S. 280 (1976). 
v. Lynaugh, Justice O'Connor argued that "it is precisely because the punishment should be directly related to the personal moral culpability of the defendant that the jury must be allowed to consider and give effect to mitigating evidence relevant to a defendant's character or record or the circumstances of the offense." 169 Indeed, character evidence introduced at the sentencing phase of a capital trial is quite often designed to be mitigating, good traits speaking as well as bad to an individual's moral character. The theory behind allowing evidence of good works or community involvement is that a convict should be permitted to rebut the judgment that his crime completely determines his moral worth. As Russell Covey writes, defendants must be allowed to introduce mitigating evidence "to prove that their crime was not consistent with, or a manifestation of, a morally defective or dangerous character." ${ }^{\text {"170 }}$ Consistent with this understanding, one theory in support of a constitutional prohibition on the execution of juveniles is that the character of a juvenile has not been sufficiently concretized. ${ }^{171}$ Justice Kennedy embraced this theory in Roper, writing that " $[t]$ he reality that juveniles still struggle to define their identity means it is less supportable to conclude that even a heinous crime committed by a juvenile is evidence of irretrievably depraved character."172 This inquiry into an individual's fundamental moral character thus is a central feature of our death penalty jurisprudence.

Actual statutory aggravators and mitigators reinforce this doctrinal focus. For the sake of economy, we will use as an example Texas, the state that accounted for more than thirty-five percent of all executions nationwide from 1977 to $2003 .{ }^{173} \mathrm{~A}$ murder qualifies as capital murder under the Texas Penal Code if any of the following conditions applies: the victim is known to be a peace officer or a fireman in the course of duty; the murder is intentionally committed in the course of committing another felony; it is a contract killing; it is in the course of a prison escape; the defendant is incarcerated and the victim is a prison employee; it is prison-

\footnotetext{
169492 U.S. 302, 327-28 (1989) (holding that, though the Eighth Amendment did not prevent the execution of mentally retarded convicts, evidence as to mental retardation could not be excluded as a mitigating factor), overruled in part by Atkins v. Virginia, 536 U.S. 304 (2002).

${ }^{170}$ Russell Dean Covey, Exorcizing Wechsler's Ghost: The Influence of the Model Penal Code on Death Penalty Sentencing Jurisprudence, 31 HASTINGS CONST. L.Q. 189, 212 (2004).

${ }^{171}$ See Elizabeth S. Scott \& Laurence Steinberg, Blaming Youth, 81 TEX. L. REV. 799, 834 (2003) (" $[\mathrm{L}] \mathrm{ike}$ the adult actor who establishes mitigation, it can be said that the adolescent's harmful act does not express his bad character; indeed, it does not manifest 'character' at all, but something else-in this case, developmental immaturity.").

${ }_{173}$ Roper v. Simmons, 125 S. Ct. 1183, 1195 (2005).

173 U.S. DEP'T OF JUSTICE, CAPITAL PUNISHMENT, 2003, at 9 (2004), available at http://www.ojp.usdoj.gov/bjs/pub/pdf/cpo3.pdit.
} 
gang related; there are multiple victims; or the victim is a child under the age of six. ${ }^{174}$ At the sentencing phase of a capital murder trial, the State must prove intent to kill and it must show that "there is a probability that the defendant would commit criminal acts of violence that would constitute a continuing threat to society." ${ }^{\prime 175}$ If the State carries its burden, the jury is further instructed to answer whether life imprisonment should be imposed instead of death, "taking into consideration all of the evidence, including the circumstances of the offense, the defendant's character and background, and the personal moral culpability of the defendant." ${ }^{, 176}$ The Texas Code of Criminal Procedure additionally reiterates that the jury "shall consider mitigating evidence that a juror might regard as reducing the defendant's moral blameworthiness." 177

To summarize, the class of crimes to which Texas applies its capital murder statute appear to be those that seem particularly socially injurious (e.g., murder of a police officer, murder in the course of a prison escape) or particularly heinous (e.g., murder of a small child). Although it is difficult to disaggregate the different rationales, we can say broadly speaking that the former category reflects a deterrence rationale and the latter reflects some form of a retribution rationale. The deterrence rationale is further vindicated by the instruction that there must be a probability of recidivism, and the retribution rationale is further vindicated by the inquiry into character and moral blameworthiness. The view of the Texas statutes is intensely personal: identical crimes may be differentially punished based on the presence of a malevolent disposition within the offender.

It is possible, of course, to argue that the inquiry into character is not grounded in retribution at all, but rather serves the purposes of specific deterrence. Covey, for example, writes that:

the doctrine of individual consideration and the decision to permit future dangerousness to be argued at the penalty phase both grow out of a philosophical belief that capital sentencing decisions should turn on non-retributive, offender-based evaluations of the defendant's character. ${ }^{178}$

\footnotetext{
${ }^{174}$ TeX. Penal Code ANN. $§ 19.03$ (Vernon 2005).

175 TeX. CODE CRIM. PROC. ANN. art. 37.0711 § 3(b) (Vernon 2005).

${ }^{176} I d . \S 3(\mathrm{e})$.

${ }^{177} I d . \S 3(\mathrm{f})(3)$.

${ }^{178}$ Covey, supra note 170 , at 209. Covey argues that this philosophical belief is the progeny of the utilitarian views of Herbert Wechsler, who helped draft the Model Penal Code. See id. at 207-24.
} 
Whatever its historical pedigree, the argument that the character inquiry speaks only to future dangerousness is both implausible and constitutionally problematic. The spectrum of positive character traits permitted under Lockett $v$. Ohio is far broader than a focus on future dangerousness would allow. As Stephen Garvey points out, ${ }^{179}$ mitigators have ranged, either in dicta or in practice, from being "a fond and affectionate uncle," 180 to assisting one's father with painting, ${ }^{181}$ to winning a choreography prize, ${ }^{182}$ to having a "peaceful nature." 183 In Texas, whose capital sentencing scheme we just discussed, a defendant's parole eligibility was not even admissible at the penalty phase until $1999 ;{ }^{184}$ three years earlier, a Texas jury sentenced to death a convict suffering from AIDS whose life expectancy was three years. ${ }^{185}$ Common sense suggests that the purpose of the character inquiry is not entirely or even primarily to assess future dangerousness but rather to establish a link between conduct and character, to "make the defendant's whole career and soul the subject of the penalty trial" $" 186$ for the purpose of judging the extent to which he has internalized norms of ethical conduct.

To the extent that prosecutors do adduce character evidence at capital trials in order to assess future dangerousness, they run into potential constitutional difficulties. As discussed, the Court has repeatedly and recently applied a heightened standard of review to capital sentencing schemes, holding that the imposition of the death penalty cannot be "excessive." 187 To suggest that execution is the least restrictive means of specific deterrence for anyone below an exceedingly rarified stratum of impulsively violent people fails the laugh test. ${ }^{188}$ Clearly some value is at play beyond preventing future crimes by the convict.

\footnotetext{
${ }^{179}$ Stephen P. Garvey, "As the Gentle Rain from Heaven": Mercy in Capital Sentencing, 81 CORNELL L. REV. 989, 1026 \& n.145 (1996).

${ }^{180}$ Lockett, 438 U.S. at 604.

${ }^{181}$ Payne v. Tennessee, 501 U.S. 808 (1991).

${ }^{182}$ Boyde v. California, 494 U.S. 370, 382 n.5 (1990).

${ }^{183}$ California v. Brown, 479 U.S. 538 (1987).

${ }^{184}$ See TeX. CodE CRIM. Proc. ANN. art. 37.071 § 2(e)(2)(B) (Vernon 2005).

${ }^{185}$ See Janet Morrow \& Robert Morrow, In a Narrow Grave: Texas Punishment Law in Capital Murder Cases, 43 S. TEX. L. REv. 979, 984-85 (2002) (discussing Dickerson v. State, No. 71,920 (Tex. Crim. App. Dec. 4 1996)).

${ }^{186}$ Robert Weisberg, Deregulating Death, 1983 SuP. CT. REV. 305, 335. In his empirical study of how capital jurors react to actual and potential aggravators and mitigators, Stephen Garvey found that while factors relating to future dangerousness are indeed highly aggravating, so too is the defendant's lack of remorse. Stephen P. Garvey, Aggravation and Mitigation in Capital Cases: What Do Jurors Think?, 98 COLUM. L. REV. 1538, 1560-61 (1998).

${ }^{187}$ See supra text accompanying notes 124-129.

${ }^{188}$ One controversial approach to incurably violent inmates has been confinement in supermax prisons, which have been characterized as having "dynamics of domination, control,
} 


\section{The Constitutionality of Character-Based Retribution}

Even if I have established that the retributive theories we rely upon in sentencing individuals to death are "personal," I have not established that they are personal in a constitutionally impermissible way. There are obvious differences, to say the least, between convicted homosexual sodomists and convicted murderers. As I have written, a convincing view of Lawrence is that it simply recognizes some social consensus that engaging in homosexual conduct does not violate a public duty, whereas murder certainly does. This distinction conforms to the moral intuitions of many, but is unsatisfying for two reasons. First, I have argued that the only way to understand Lawrence as a creature of the doctrinal tradition, rather than as a sui generis determination that writing moral approbation of gays into statutes is unconstitutional, is to recognize the principle that selfdefinitional conduct is protected by substantive due process in a way that other conduct is not. Second, this distinction does not in itself explain why bad character may be a but-for cause of a capital sentence.

Imagine the Texas legislature enacts the following amendment to its capital murder statute:

Capital Murder Sodomy. A person commits an offense if the person commits murder as defined under Section 19.02(b)(1) under the following conditions:

(a) the person commits the murder while committing sodomy against a minor; and

(b) the person and the minor are of the same sex.

subordination, and submission [that] are fundamentally different from those in regular maximum security prisons." Leena Kurki \& Norval Morris, The Purposes, Practices, and Problems of Supermax Prisons, 28 CRIME \& JUST. 385, 390 (2001). Little empirical research has emerged on the effectiveness of supermax prisons at reducing violence, but for one study's take, see Chad S. Briggs, Jody L. Sundt, \& Thomas C. Castellano, The Effect of Supermaximum Security Prisons on Aggregate Levels of Inmate Violence, 41 CRIMINOLOGY 1341 (2003) (finding that supermaxes in Illinois, Arizona, and Minnesota could not be justified as a means of increasing inmate safety but finding mixed results as to staff safety). See also Richard L. Lippke, Against Supermax, $21 \mathrm{~J}$. APPLIED PHILOSOPHY 109, 113 (2004) (arguing that proponents have not carried their burden of demonstrating that supermax facilities are more effective than ordinary solitary confinement). The fact that states themselves are the typical proponents of the argument that supermax prisons reduce violence should itself raise red flags as to the appropriateness of the future dangerousness inquiry at its present level of generality. 
Such a statute would pose obvious difficulties under Lawrence, and the Supreme Court suggested as much in Limon v. Kansas. ${ }^{189}$ Yet Lawrence does not on its own terms furnish any grounds upon which to distinguish "gay" people from "inwardly wicked" or otherwise morally blameworthy people. Justice Kennedy expressly eschews "mandate[ing] [his] own moral code," $" 190$ and yet many Americans believe that homosexuality reflects deep character flaws, and moreover that these flaws are particularly likely to manifest themselves as crimes of moral turpitude. If we are to take Justice Kennedy's words seriously, they must mean that the Court must be, to borrow from the First Amendment jurisprudence, content-neutral. ${ }^{191}$

If this is so, the crucial question is content-neutral with respect to what? Again, a tempting option is to say that the Court must be content-neutral within the category of acts that individuals have the moral freedom to engage in. One does not, of course, have a liberty right to engage in criminal conduct, but no a priori principle excludes homosexual sodomy from the family of criminal conduct. Without a theory of the instrumental value of same-sex sexual relations, anti-sodomy laws are just another example of "laws representing essentially moral choices." 192 The theory articulated in Lawrence, I have argued, is that anti-sodomy laws breach the status-conduct divide by punishing for who someone is rather than for what they do. And yet the retributive rationale upon which our death penalty doctrine appears largely to rely does the same, for it attaches penological relevance to the substance of an individual's ontological commitments.

Although Lawrence is perhaps our most obvious jurisprudential paean to this kind of content-neutrality in punishment, it is not our only one. The Court expressed a similar idea more than forty years ago when it held in Robinson v. California that punishing "status" crime violates the Eighth Amendment. ${ }^{193}$ As Justice Douglas wrote in concurrence, "[T]he principle that would deny power to exact capital punishment for a petty crime would also deny power to punish a person by fine or imprisonment for being sick." 194 It will be objected that the morally depraved is "sick" not in the medical but in the colloquial sense. Whereas sickness or addiction is simple bad luck, a mentally competent person, even one with bad "constitutive" luck, ${ }^{195}$ commits a heinous murder as an act of will. ${ }^{196}$ Even without

\footnotetext{
189539 U.S. 955 (2003); see supra text accompanying notes 159-162.

${ }^{190}$ Lawrence v. Texas, 539 U.S. 558, 571 (2003).

${ }^{191}$ See, e.g., United States v. Grace, 461 U.S. 171 (1983) (subjecting time, place, and manner restrictions on speech in public forums to content-neutrality and heightened scrutiny).

${ }^{192}$ Bowers v. Hardwick, 478 U.S. 186, 196 (1986).

${ }^{193}$ Robinson v. California, 370 U.S. 660 (1962).

${ }^{194}$ Id. at 676 (Douglas, J., concurring).

${ }^{195}$ See ThOMAS NAGEL, Moral Luck, in MORTAL Questions 24, 28 (1979).
} 
engaging the determinist's response to this objection, ${ }^{197}$ it will suffice to note that Lawrence does not expressly rely on a judgment about whether the status defined by the conduct was willful or not.

The illiberality of punishing someone for having a disfavored constitution also finds expression in the Bill of Attainder clauses. Those clauses were meant to embody the idea that it is wrong for a criminal statute "to designate[] criminals rather than crimes." 198 Writes Akhil Amar, "Both legislation and adjudication must be suitably impersonal. Neither legislators nor judges may punish me simply because they do not like me." ${ }^{\prime 199}$ Neither, I argue, can they enhance your sentence for that reason. It is in this spirit that Lawrence declared "we don't like you" an ad hominem, not a principle of criminal liability. Amar suggests that one's "intent and predispositions" may be relevant to "punishment and deterrence" once a person "has violated a legitimate criminal law. ${ }^{, 200}$ Post-Lawrence, at least, I suggest that one's predispositions are relevant only to the extent that they help the State to effectuate legitimate penological objectives such as sentence length, correctional classification, and rehabilitative regimen. To say, without more, that one must die because he is morally depraved ignores the command of impersonality.

\section{Responding to Objections}

I have already attempted, through a clarification of my methodology, to answer the overriding objection to my thesis, that Lawrence, like many substantive due process decisions before it, is simply sui generis extension of fundamental rights. I can anticipate at least four additional grounds for skepticism. First, my argument seems deeply counterintuitive, in that it appears to suggest that the more committed the criminal, the less he may be punished. Second, social consensus may not play the same role in criminal sentencing as it plays in Lawrence, and in any event seems a weak ground on which to rest a right to avoid the death penalty. Third, my thesis may appear to require that belief in free will be read out of the Constitution, which is inconsistent with any reasonable theory of judicial restraint. Finally, the role mitigation evidence plays in my scheme is uncertain, if the State is to take seriously the mandate of content-neutrality. I address each objection in turn.

${ }^{196}$ See MOORE, supra note 165, at 217.

${ }^{197}$ See Subsection II.B.3.c, supra.

${ }^{198}$ Amar, supra note 18, at 211.

${ }^{199} \mathrm{Id}$. at 210.

${ }^{200} I d$. at 218. 


\section{a. On Intuition}

Plainly, our moral intuitions do not support the claim that connecting criminal conduct to bad character should decrease the range of available punishments. Indeed, many have argued that retribution is the moral basis for our intuitive disgust at excessive punishment. ${ }^{201}$ The concept of "desert," being inherently normative, seems defeated if we reject our moral intuitions as to who merits particular punishments.

I offer two responses to this argument. First, on my account, connecting criminal conduct to bad character does not decrease the range of available punishments; it merely fails to increase it. The argument is not that bad character makes one less morally culpable, but rather that bad character is simply not relevant to the State's imposition of criminal punishments. ${ }^{202}$ The inquiry, where conducted for improper purposes, simply exceeds the legitimate power of the State. This restated argument remains counterintuitive (if less so), but-and this amounts to the second response-much of our constitutional doctrine fails to conform to our moral intuitions. Our Constitution does not require that punishment be just; it requires that certain protected liberty interests be respected by the State. Consider, to take but two examples, the exclusionary rule and the double jeopardy clause. Both reject dominant moral intuitions about just outcomes but vindicate other values that the polity deems significant.

The principles of Lawrence-style metaprivacy hold that one's interest in metaphysical autonomy is one such protected value. The State may neither impose nor increase one's punishment based on a moral judgment about the commitments that that autonomy entails. I will have more to say in Part III about our intuitions about competing theories of value, but let it suffice for now to say that Lawrence emphasizes and reinforces a theoretically controversial doctrinal position, that that autonomy is "presumptive,"203 and neither prostrates before a community's contrary moral claims nor vanishes at the prison gate.

\section{b. Social Consensus Redux}

\footnotetext{
201 See, e.g., COREy LANG BRETTSCHNEIDER, PUnishment, Property AND Justice 33 (2001).

${ }^{202}$ I table for the purposes of this paper whether bad character may be relevant to non-retributive rationales for punishment.

${ }^{203}$ Lawrence v. Texas, 539 U.S. 558, 562 (2003) ("Liberty presumes an autonomy of self that includes freedom of thought, belief, expression, and certain intimate conduct."); Henkin, supra note 271, at 1411; see text accompanying note 352 .
} 
We have seen that social consensus plays a role in delineating the protected interests in Lawrence, namely in identifying self-definitional conduct. ${ }^{204}$ There are at least two potential problems in extending this logic to criminality. First, even if we accept the command of content-neutrality, it is not obvious that the requisite determination has even been made in the criminal context. Writes Jed Rubenfeld:

When a person obeys the law against murder, or almost any other law, his life is constrained but not usually informed or taken over to any substantial degree with a set of new activities and concerns. He is not thrust into a set of new institutions or relations. The category of "non-murderer" is essentially a formal one; it is not a defined role or identity with substantial, affirmative, institutionalized functions. ${ }^{205}$

Criminals may actualize their autonomy through criminal behavior, or they may not. Moreover, our evidence of such actualization-the character evidence introduced at the sentencing phase of a trial-may not indicate the kind of metacommitment thought relevant in Lawrence.

This objection proves too much. Participating in homosexual sodomy does not necessarily reflect an attempt at self-actualization, either, and indeed, Justice Scalia was deeply skeptical of any distinction between homosexual sodomy and nudism in their respective substantiations of selfdefining conduct. ${ }^{206}$ The question is whether having a moral character tied to criminal behavior is, from the vantage point of social consensus, more like nudism or more like homosexual sodomy. That is, does social consensus indicate that the criminal behavior of, say, Todd Rizzo, is incidental to his being, or that it is constitutive of it?

The inquiry has two parts: First, I must demonstrate that social consensus is the instrument of decisionmaking. Then, I must show that the judgment made by social consensus in the criminal sentencing context is like the judgment referenced in Lawrence. The first issue is essentially answered by stipulation. A statute listing moral blameworthiness and bad character as aggravators is itself a powerful demonstration of social consensus. In a capital sentencing trial, a legislature in essence delegates to the jury its role as an instrument of that consensus.

\footnotetext{
${ }^{204}$ See supra text accompanying notes 88-90.

205 Jed Rubenfeld, The Right of Privacy, 102 HARV. L. REV. 737, 793 (1989).

${ }^{206}$ Lawrence, 539 U.S. at 601 (Scalia, J., dissenting).
} 
The answer to the second issue is more difficult. For assistance, I turn to the Supreme Court case of Dawson v. Delaware. ${ }^{207}$ In Dawson, the State of Delaware sought to rebut mitigating "good" character evidence of the defendant's kindness and prison good time credits with "bad" character evidence that Dawson belonged to an avowedly racist gang, the Aryan Brotherhood. $^{208}$ The Court refused to allow the evidence on the grounds that the First Amendment prevents a state from "employing evidence of a defendant's abstract beliefs at a sentencing hearing when those beliefs have no bearing on the issue being tried. ${ }^{, 209}$ Certainly, belonging to a racist gang might indicate "bad" moral character, but only the fact that the evidence was not demonstrably relevant to Dawson's criminal tendencies prevented it from being used. ${ }^{210} \mathrm{~A}$ jury weighing aggravating factors is not asked to judge whether a convict may happen to be a bad person incidental to being a criminal, but rather whether he is a criminally bad person, one whose moral commitments tend towards the criminal activity for which he has been convicted. The judgment being made is whether criminal activity is a manifestation of a deeper identity. Withholding an enhanced punishment but for the presence of this identity is inconsistent with Lawrence, just as withholding enhanced punishment but for the presence of abstract beliefs and political affiliations is inconsistent with First Amendment doctrine.

There is, however, a second objection related to social consensus. It may seem morally inappropriate to accord so prominent a role to social consensus in delineating so important a right as the right to life. This complaint is misplaced. We rely on social consensus for decisions of life and death all the time, most explicitly in the Eighth Amendment, ${ }^{211}$ but also, as I have noted, implicitly in the Anglo-American jury system itself. It may indeed be morally improper to grant so much weight to evolving social standards, but convention plays at least as powerful a role in our constitutional law as moral philosophy.

\section{c. On Free Will}

If this paper's argument requires that the State adopt a determinist position on human agency, that may be sufficient reason to reject it. One

\footnotetext{
207503 U.S. 159 (1992).

${ }^{208} \mathrm{Id}$. at $167-68$

${ }^{209} \mathrm{Id}$. at 168 (emphasis added).

${ }^{210}$ See id. at 167 ("Delaware might have avoided this problem if it had presented evidence showing more than mere abstract beliefs on Dawson's part, but on the present record one is left with the feeling that the Aryan Brotherhood evidence was employed simply because the jury would find these beliefs morally reprehensible.").

${ }^{211}$ See Trop v. Dulles, 356 U.S. 86, 100-01 (1958); supra notes 147-148 and accompanying text.
} 
explanation for the principle of content-neutrality that this paper has sketched would be that someone with a criminal constitution cannot be held responsible for his criminal actions. On this view, Lawrence rested on the idea that gay identity is not freely chosen, and therefore the conduct associated with gay identity should not be criminalized. If one also cannot choose to be a committed criminal, it would follow that punishing on this basis is also impermissible. Imputing to the Constitution so controversial a philosophical view would be so aggressively radical that we would have to reject it on its face.

A determinist explanation is not the only one, however. An alternative position is an epistemological one. Even if criminals are exercising their free will in committing crimes, how is one ever to know? Evidence of inherent bad character may demonstrate a decreased likelihood that a bad act is freely chosen. A third position is that Lawrence-style metaprivacy does not accept any determinist account, but simply requires that the State take no position, as retributive punishment may, ${ }^{212}$ on whether people with criminal character are exercising free will in committing crimes. Finally, Lawrence may have nothing whatsoever to do with free will, and may just be a case about the appropriate limits of the State's power to judge identities. This list does not exhaust the possibilities, but it makes the point, namely that my argument makes no necessary assumption about the constitutional legitimacy of believing in free will.

\section{d. On Mitigation}

If this paper's argument is correct, and the State must indeed be content-neutral, does it mean that, contrary to Lockett $v$. Ohio, ${ }^{213}$ a capital jury no longer may hear evidence at the penalty phase that, say, church attendance, random acts of kindness, or a generally pacific nature demonstrate that a defendant deserves to live? One might be tempted reflexively to say no, on the grounds that Lawrence is about making only pejorative moral judgments about constitutive character. Since mitigation evidence is not used as a form of punishment, it falls outside the scope of the principles of metaprivacy. But anytime the State decreases a punishment based on mitigating evidence, it necessarily creates a differential between people who possess the trait in evidence and those who do not. Those convicts for whom mitigation evidence is unavailing are

\footnotetext{
${ }^{212}$ But see NOZICK, supra note 167, at 393 (arguing that a belief in determinism is not inconsistent with retributive punishment).

${ }^{213}$ Lockett v. Ohio, 438 U.S. 586 (1978).
} 
executed, though the presence of sufficient mitigating character evidence would have spared them. Content-neutral this is not.

The position this paper takes, then, as it must, is that certain mitigating evidence is equally capable of violating the principles of Lawrence. Where such evidence is adduced to vindicate a belief that certain personal metacommitments are deontologically more worthy of enhanced punishment than others, it must be excluded.

Even if the principles of metaprivacy prohibit a particular form of retributive punishment, as outlined above, the constitutionality of capital punishment generally remains an open question. The Supreme Court has reiterated recently that the Constitution "does not mandate adoption of any one penological theory," $" 214$ though the Court has cited only deterrence and retribution as acceptable rationales for capital punishment. ${ }^{215}$ It will be fruitful to examine whether the death penalty can withstand scrutiny under wholly non-retributive rationales for punishment, ${ }^{216}$ but that inquiry is beyond the scope of this paper. Rather, the remainder of this paper examines the extent to which the relationship between metaprivacy and punishment that I have sketched comports with the existing legal framework. If not, it would constitute an objection more general, and potentially more fatal, than any I have heretofore considered.

\footnotetext{
${ }^{214}$ Ewing v. California, 538 U.S. 11, 25 (2003) (quoting Harmelin v. Michigan, 501 U.S. 957, 999 (1991) (Kennedy, J., concurring in part and concurring in the judgment)).

${ }^{215}$ Roper v. Simmons, 125 S. Ct. 1183, 1196 (2005). An additional potential rationale that remains unexplored doctrinally is an "expressive" rationale. See, e.g., Joel Feinberg, The Expressive Function of Punishment, in PHILOSOPHY OF LAW 761, 762 (Joel Feinberg \& Jules Coleman eds., 2004) ("Punishment is a conventional device for the expression of attitudes of resentment and indignation, and of judgments of disapproval and reprobation, either on the part of the punishing authority himself or of those 'in whose name' the punishment is inflicted.").

${ }^{216}$ It may be useful to ask, for example, what deference is owed to any legislative evidence supporting a general deterrence rationale, especially in light of the Court's recent interest in scrutinizing legislative fact-finding in federalism cases. See, e.g., William W. Buzbee \& Robert A. Schapiro, Legislative Record Review, 54 STAN. L. REV. 87 (2001) (discussing Garrett, Lopez, Morrison and City of Boerne). Virtually all will agree that the empirical debate is inconclusive at best. See Michael L. Radelet \& Ronald L. Akers, Deterrence and the Death Penalty: The Views of the Experts, 87 J. CRIM. L. \& CRIMINOLOGY 1, 8 (1996) (finding that eighty percent of criminologists believe that according to present literature the death penalty has no significant deterrent effect). But see Hashem Dezhbakhsh et al., Does Capital Punishment Have a Deterrent Effect? New Evidence from Postmoratorium Panel Data, 5 AM. L. \& ECON. REV. 344 (2003) (suggesting that executions may save eighteen lives on average). At a higher level of generality, it may be necessary to consider the extent to which general deterrence itself represents a competing moral claim that cannot trump an individual's right to metaprivacy.
} 


\section{ON CONSTITUTIONAL FIT}

Ronald Dworkin has famously described the analytic process a principled judge goes through in adjudicating hard cases. He argues that she must observe the doctrine of "political responsibility." 217 That is, the principle that gives rise to her rule of decision must "fit" settled legal rules and practices; it must be "shown to be consistent with earlier decisions not recanted, and with decisions that the institution is prepared to make in . . hypothetical circumstances." ${ }^{218}$ Then, if multiple decisional rules fit the existing legal landscape, the jurist chooses the normative theory that best justifies the present body of law. ${ }^{219}$ I have thus far been relatively inattentive to these external interpretive constraints. This Part aims to palliate, if not quite cure, this lingering rhetorical ailment by demonstrating that my interpretation of the relationship between metaprivacy and punishment is neither a departure from settled rules nor even a departure from extant understandings of settled rules. Section III.A situates my interpretation of Lawrence within the broader privacy and First Amendment doctrine. Section III.B examines and demonstrates this paper's comity with extant understandings of this doctrine, understandings that ultimately must deny a place for the State to draw distinctions between the personal ethical commitments of the individuals within its polity.

\section{A. Doctrinal Fit}

This Section discusses the emergence of the right to privacy as a distinct doctrinal category. Subsection III.A.1 lays out the contours of the privacy doctrine as it has developed in three incarnations: tort privacy, Fourth Amendment privacy, and fundamental decision privacy. I argue that the principle of metaprivacy has lingered beneath each incarnation, and has become progressively more dominant over time. Subsection III.A.2 argues that enunciating a principle of Lawrence as metaprivacy helps to harmonize the latent conflict between First Amendment hate speech and expressive association doctrines.

\section{Constitutional Privacy}

\footnotetext{
${ }^{217}$ RONALD DWORKIN, TAKING RIGHTS SERIOUSLY 87 (1977).

${ }^{218} \mathrm{Id}$. at 88.

${ }^{219}$ See id. at 106-07.
} 
The meaning of the right to privacy is hardly self-evident. Whatever the success of the many efforts to give the right substance and consistency, ${ }^{220}$ these efforts have not wholly infiltrated Supreme Court doctrine and the common law. The privacy right as understood in American jurisprudence encompasses a potpourri of distinct if related concepts: the freedom not to have one's name or likeness appear in advertisements without consent; ${ }^{221}$ the freedom from government intrusion into one's home and personal effects; ${ }^{222}$ the freedom to hold a meeting without a government mole present; ${ }^{223}$ the freedom to use contraceptives; ${ }^{224}$ the freedom to marry; ${ }^{225}$ and the freedom to have non-commercial sexual relations with consenting adults $^{226}$ all have been defended under the same banner. The privacy doctrine can be segregated into at least three broad categories: tort privacy, Fourth Amendment privacy, and fundamental decision privacy. ${ }^{227}$ To elucidate the thread that runs through these doctrinal species of privacy, I briefly discuss each in turn.

\section{a. Tort Privacy}

Privacy has a quotidian meaning that we all essentially understand, even if it escapes precise definition. Our right to privacy protects us from the nonconsensual prying of others into matters we consider to be personal or intimate. Thus it protects us from peeping Toms, both literal and metaphorical. When Samuel Warren and Louis Brandeis wrote their seminal 1890 article, The Right to Privacy, ${ }^{228}$ they had this quotidian meaning in mind. According to William Prosser, Warren was upset at the aggressive coverage the Boston newspapers had been giving to his wife's high society parties, particularly the recent wedding of the Warrens'

${ }^{220}$ See, e.g., Charles Fried, Privacy, 77 YALE L.J. 475 (1967) (emphasizing privacy's value as a necessary instrument to the achievement of fundamental interpersonal relationships); Jeffrey $\mathrm{H}$. Reiman, Privacy, Intimacy, and Personhood, 6 PHIL. \& PUB. AFFAIRS 26 (1976) (casting doubt on Fried's view as, inter alia, too market-oriented, and instead grounding the fundamentality of privacy in its role in staking a claim to personhood); Rubenfeld, supra note 205 (elaborating an "anti-totalitarian" conception of privacy).

${ }^{221}$ See, e.g., Pavesich v. New England Life Insurance Co., 50 S.E. 68 (Ga. 1905).

${ }^{222}$ See, e.g., Olmstead v. United States, 277 U.S. 438 (1928) (Brandeis, J., dissenting).

${ }^{223}$ See NAACP v. Alabama, 357 U.S. 449 (1958).

${ }^{224}$ See, e.g., Griswold v. Connecticut, 381 U.S. 479 (1965); see also Eisenstadt v. Baird, 405 U.S. 438 (1972) (extending Griswold to single people).

${ }^{225}$ See, e.g., Zablocki v. Redhail, 434 U.S. 374 (1978).

${ }^{226}$ See Lawrence v. Texas, 539 U.S. 558 (2003).

${ }^{227}$ Some have argued for more. See, e.g., Ken Gormley, One Hundred Years of Privacy, 1992 WISC. L. REV. 1335 (identifying "First Amendment" privacy and "state constitutional" privacy as additional categories).

${ }^{228}$ Samuel D. Warren \& Louis D. Brandeis, The Right to Privacy, 4 HARV. L. REV. 193 (1890). 
daughter. ${ }^{229}$ Warren's revenge was to conspire with his former law partner Brandeis to declare, in the pages of the Harvard Law Review, a "right to be let alone." ${ }^{230}$ Each individual, they argued, has a right to determine "to what extent his thoughts, sentiments, and emotions shall be communicated to others," 231 to decide, that is, "whether that which is his shall be given to the public." 232 According to Warren and Brandeis, the palpable injury to the individual caused by unwarranted invasions of this right is and should be actionable. While Warren and Brandeis did not invent the privacy tort, theirs represents the first attempt to define its contours comprehensively.

Over the next decade, several courts also began to recognize a common law right to determine the uses of one's image by others. ${ }^{233}$ Among the most notable early cases is Pavesich v. New England Life Insurance Co., in which the Georgia Supreme Court held that a plaintiff artist, Paolo Pavesich, could invoke his privacy rights in suing an insurance company for the use of his endorsement and his image in an advertisement without his consent. ${ }^{234}$ During an extensive discussion of the development of the right of privacy since the Warren and Brandeis article, Justice Cobb wrote for the Court that "[w]hen, as here, there is an alleged invasion of some personal right, or privilege, the absence of exact precedent and the fact that early commentators upon the common law have no discussion upon the subject are of no material importance in awarding equitable relief."235 Some blowback occurred, ${ }^{236}$ but rarely had an academic work so immediately and palpably affected the development of common law rights and duties.

\footnotetext{
${ }^{229}$ William L. Prosser, Privacy, 48 CAL. L. REV. 383, 383 (1960).

${ }^{230}$ Warren \& Brandeis, supra note 228, at 195 (quoting THOMAS M. COOLEY, COOLEY ON TORTS 29 (2d ed. 1888)). The anecdote has some holes. As Ken Gormley notes, the Warrens' daughter was six years old in 1890. See Gormley, supra note 227, at 1349.

${ }^{231}$ Warren \& Brandeis, supra note 228, at 198.

${ }^{232} I d$. at 199.

${ }^{233}$ See, e.g., Corliss v. E.W.Walker Co., 64 F.280, 282 (C.C.D. Mass. 1894) (declaring in dicta that "the right of a private individual to prohibit the reproduction of his picture or photograph should be recognized and enforced"); Marks v. Jaffa, 26 N.Y.S. 908, 909 (N.Y. Sup. Ct. 1893) (enjoining the use of the plaintiff actor's name and photograph in a newspaper popularity contest); Mackenzie v. Soden Mineral Springs Co., 18 N.Y.S. 240 (N.Y. Sup. Ct. 1891) (enjoining the use of a doctor's name in an advertisement for certain medicinal pastilles); Schuyler v. Curtis, 15 N.Y.S. 787 (N.Y. Sup. Ct. 1891) (enjoining the erecting of an unauthorized statue to commemorate the philanthropy of the plaintiff's deceased family member); Manola v. Stevens (N.Y. Sup. Ct. 1890), in N.Y. Times, June 15, 18, 21, 1890 (enjoining a photographer from publishing a photograph of an actress wearing tights on stage).

${ }^{234}$ Pavesich v. New England Life Insurance Co., 50 S.E. 68 (Ga. 1905).

${ }^{235} \mathrm{Id}$. at 78 .

${ }^{236}$ See, e.g., Roberson v. Rochester Folding Box Co., 64 N.E. 442, 447 (N.Y. 1902) (denying injunctive relief to a plaintiff who objected to the unauthorized use of her portrait in flour advertisements because "the so-called 'right of privacy' has not yet found an abiding place in our jurisprudence."). The Roberson case was much criticized, so much so that a member of the panel
} 
The twentieth century saw the right to control the use of one's image in public establish itself still more firmly at common law, ${ }^{237}$ under a handful of state statutes, ${ }^{238}$ and in the Restatement of Torts. ${ }^{239}$ In 1960, Prosser advanced the legal community's understanding of "private" privacy rights by identifying four distinct torts: 1) "[i]ntrusion upon the plaintiff's seclusion or solitude, or into his private affairs"; 2) "[p]ublic disclosure of embarrassing private facts about the plaintiff"; 3 ) "[p]ublicity which places the plaintiff in a false light in the public eye"; and 4) "[a]ppropriation, for the defendant's advantage, of the plaintiff's name or likeness." ${ }^{240}$ What these four categories have in common is that their recognition allows individuals to protect their public personae from unauthorized appropriation. One hears in Warren and Brandeis, however, echoes of a broader philosophical claim, even if they advance it only instrumentally. The right to privacy, they write, is "part of the more general right to the immunity of the person, - the right to one's personality." ${ }^{241}$ A right to "personality" is by no means self-defining, though the right to private control of one's public image is one of several options. I consider other contenders below.

\section{b. Fourth Amendment Privacy}

The Brandeis legacy is, of course, much larger than the privacy tort. Brandeis's views on privacy must be read in pari materia with his general view of the appropriate relationship between individuals and the social and political institutions that threaten to dominate their lives. Brandeis was averse to the commodification of our social life and what he referred to as "the curse of bigness" both in the private sector and in government. ${ }^{242}$ For Brandeis, writes David Levy, "[t]he explosion of heavy industry seemed to carry with it unlimited possibilities for blind materialism, political corruption of the worst sort, class warfare and hatred, quite unacceptable

\footnotetext{
found it necessary to write a law review article to defend the decision. See Prosser, supra note 229, at 385 (discussing Denis O'Brien, The Right of Privacy, 2 CoLuM. L. REV. 437 (1902)).

${ }^{237}$ By 1960, only four states courts-in Rhode Island, Nebraska, Texas, and Wisconsin-had expressly rejected a common law privacy right. Prosser, supra note 229, at 388 .

${ }^{238}$ See, e.g., Act of Apr. 6, 1903, ch. 132, §§ 1-2, 1903 N.Y. Laws 308 (making appropriation of one's "name, portrait or picture" for the purposes of trade or advertising is a misdemeanor and providing a cause of action in equity); Utah Code Ann. $\S \S 76-4-8,9$ (1953) (making appropriation a misdemeanor); Va. Code Ann. § 8.01-40 (1950) (providing for a suit in equity or for damages).

${ }^{239}$ See RESTATEMENT OF TORTS $\$ 867$ (1939).

${ }^{240}$ Prosser, supra note 229, at 389.

${ }^{241}$ Warren \& Brandeis, supra note 228, at 207.

${ }^{242}$ See PHILIPPA STRUM, BRANDEIS: BEYOND PROGRESSIVISM 72-99 (1993).
} 


\section{Beyond Lawrence: Metaprivacy and Punishment}

limitations on human freedom, the death of initiative and healthy competition, the gravest threat to traditional standards of democracy itself." 243 Like Mill's, Brandeis's individualism was civic-minded; he believed that the political dialogue necessary for a healthy democratic state presupposed a respect for individual liberty. ${ }^{244}$

Naturally then, Brandeis's concern for privacy rights was not limited to the private sphere. As Justice Brandeis, he articulated, in dissent in Olmstead v. United States, ${ }^{245}$ the Court's first comprehensive recognition of a right to privacy against the State:

The makers of our Constitution undertook to secure conditions favorable to the pursuit of happiness. They recognized the significance of man's spiritual nature, of his feelings and of his intellect. They knew that only a part of the pain, pleasure and satisfactions of life are to be found in material things. They sought to protect Americans in their beliefs, their thoughts, their emotions and their sensations. They conferred, as against the Government, the right to be let alone- the most comprehensive of rights and the right most valued by civilized men. Every unjustifiable intrusion by the government upon the privacy of the individual, whatever the means employed, must be deemed a violation of the Fourth Amendment. ${ }^{246}$

As Brandeis recognized, the Fourth Amendment represents the Constitution's most evident application of the spirit of the privacy tort to the public sphere. ${ }^{247}$ It asks, in effect, under what circumstances and subject to what limitations government agents may invade an individual's private

\footnotetext{
${ }^{243}$ See David W. Levy, Brandeis and the Progressive Movement, in BRANDEIS AND AMERICA 99, 111 (Nelson L. Dawson ed., 1989). Brandeis's aversion to "bigness" manifested itself in, for example, a suspicion of technology. He was a copious letter-writer who used telephones only when necessary. Brandeis wrote at least 2,500 letters to his wife and daughter alone over a fiftyyear period, Melvin I. Urofsky, The Brandeis Agenda, in BRANDEIS AND AMERICA 99, 133 (Nelson L. Dawson ed., 1989), and kept his horse and buggy until it was banned from the streets of Washington, D.C. in the 1920s, see Levy, supra, at 103.

${ }^{244}$ See STRUM, supra note 242, at 2.

${ }^{245} 277$ U.S. 438, 471 (1928) (Brandeis, J., dissenting).

${ }^{246} \mathrm{Id}$. at 478 .

${ }^{247}$ See Akhil Reed Amar, Fourth Amendment First Principles, 107 HARV. L. REV. 757, 758 (1994) (commenting that the "global command" of the Fourth Amendment "that all government searches and seizures be reasonable sounds not in criminal law, but in constitutional tort law"); Richard A. Posner, Rethinking the Fourth Amendment, 1981 SuP. CT. REV. 49, 51 (declaring that the Fourth Amendment protects "interests in bodily integrity, mental tranquility, and freedom of movement traditionally protected by tort actions").
} 
space and search her belongings against her will. The Fourth Amendment does not mention "privacy" in express terms. The right it speaks of, that "of the people to be secure in their persons, houses, papers, and effects, against unreasonable searches and seizures . . ., "248 appears to sound more in property than in privacy. ${ }^{249}$ In the years since Olmstead, however, the Court has attempted to give definition to the meaning of the word "persons" in the search-and-seizure context.

The Court's earliest effort at Fourth Amendment interpretation came in Boyd v. United States, a challenge to a government subpoena of an invoice for allegedly illegally imported plate glass. ${ }^{250}$ Even though the case did not involve a literal, physical search or seizure, the Court held that the compelled production of such "private papers" violated the Fourth Amendment. Referring to the great English case of Entick v. Carrington, ${ }^{251}$ in which Lord Camden voided the seizure of John Entick's private papers in a seditious libel investigation against him, Justice Bradley wrote for the Court that:

[i]t is not the breaking of [Entick's] doors, and the rummaging of his drawers, that constitutes the essence of the offence; but it is the invasion of his indefeasible right of personal security, personal liberty and private property, where that right has never been forfeited by his conviction of some public offence $\ldots{ }^{252}$

The Fourth Amendment protected far more than just the security of the people in their "persons, houses, papers, and effects;" these, the Court suggested, were but a shorthand for "the sanctity of a man's home and the privacies of life." 253

Two of Boyd's many take-home points are especially relevant to our discussion of constitutional privacy doctrine. First, Boyd applied, at least to private effects, the nineteenth-century analogue of a heightened scrutiny test. An individual's right to her private personal items is described as "indefeasible," what the modern Court would call "fundamental." Second, and relatedly, Lord Camden's Entick opinion relies heavily on the supposition that " $[\mathrm{t}] \mathrm{he}$ great end for which men entered into society was to

\footnotetext{
${ }^{248}$ U.S. Const. amend. IV.

249 See Morgan Cloud, The Fourth Amendment During the Lochner Era: Privacy, Property, and Liberty in Constitutional Theory, 48 STAN. L. REV. 555, 562 (1996).

${ }^{250}$ See Boyd v. United States, 116 U.S. 616 (1886).

${ }^{251} 19$ Howell's State Trials 1029 (C.P. 1765).

${ }^{252}$ Boyd, 116 U.S. at 630.

${ }^{253} \mathrm{Id}$.
} 
secure their property."254 Although Boyd arguably announced a more broadly applicable principle than that a man's home is his castle, this is essentially the proposition for which it stands. ${ }^{255}$ As Morgan Cloud writes, "Boyd is the Fourth Amendment's analogue of Lochner, employing the same kind of natural law-based reasoning linking liberty and property rights to strike down a statute." ${ }^{, 256}$ History has been more kind to Boyd than to Lochner, but only barely.

Three Supreme Court cases merit particular mention in exploring the doctrinal segue from Boyd to the themes of greatest relevance to this paper. The first is Olmstead, a challenge to a federal wiretap. The Olmstead majority limited Boyd's expansive Fourth Amendment protections, ruling that they applied only to either "an official search and seizure of [one's] person, [or] papers [or] tangible material effects," or "an actual physical invasion of [one's] house 'or curtilage' for the purpose of making a seizure. ${ }^{, 257}$ Neither a wiretap nor any other form of electronic surveillance fit this Spartan definition. ${ }^{258}$ The majority opinion contained none of the symbolic language about "the privacies of life," prompting Brandeis's suggestion that the Court was placing an "unduly literal construction" upon the Fourth Amendment. ${ }^{259}$

A pair of Warren Court decisions would partially vindicate Brandeis but, in so doing, would substantially contribute to the confusion in this area. First, in Warden v. Hayden, ${ }^{260}$ a case involving a warrantless search that yielded various personal items of a man eventually convicted of armed robbery, the Court held that the search was valid even though the items obtained were "mere evidence" rather than "instrumentalities, fruits, or contraband." 261 The reason the so-called "mere evidence" rule was no longer applicable, Justice Brennan wrote, was because the protections of the Fourth Amendment attached not to particular categories of property but to

\footnotetext{
${ }^{254}$ Boyd, 116 U.S. at 627 (quoting Entick, 19 Howell's State Trials at 1066).

${ }^{255}$ See, e.g., Payton v. New York, 445 U.S. 573, 582 n. 17 (1980) (citing Boyd for the notion that "[a]t the core of the Fourth Amendment . . . is the fundamental concept that any governmental intrusion into an individual's home or expectation of privacy must be strictly circumscribed"); Amar, supra note 247, at 788 (calling Boyd a relic of "Lochner-era property worship"); Cloud, supra note 249, at 578 (describing the "property-based concepts" of Boyd as "a fundamental part of Fourth Amendment doctrine" for the next eighty years).

${ }^{256}$ Cloud, supra note 249, at 560-61 (citing Lochner v. New York, 198 U.S. 45 (1905)).

257 Olmstead v. United States, 277 U.S. 438, 466 (1928). "Curtilage" is the enclosed land surrounding a house.

${ }^{258}$ A conversation is now considered "tangible" for Fourth Amendment purposes. See Berger v. New York, 388 U.S. 41, 52 (1967).

${ }^{259}$ Olmstead, 277 U.S. at 476 (Brandeis, J., dissenting).

260387 U.S. 294 (1967).

${ }^{261}$ Id. at 300.
} 
individuals: "We have recognized that the principal object of the Fourth Amendment is the protection of privacy rather than property, and have increasingly discarded fictional and procedural barriers rested on property concepts." 262

Seven months later the Court expanded upon its newfound Fourth Amendment privacy conception in Katz v. United States, ${ }^{263}$ which held that the exclusionary rule applied to an FBI recording of a conversation on a device placed outside a telephone booth. "[T]he Fourth Amendment protects people, not places," wrote Justice Stewart. "What a person knowingly exposes to the public, even in his home or office, is not a subject of Fourth Amendment protection. But what he seeks to preserve as private, even in an area accessible to the public, may be constitutionally protected." ${ }^{264}$ The test of whether a situation or location is one sought to be preserved as private that emerged from Katz is spelled out largely in the concurrence of Justice Harlan. ${ }^{265} \mathrm{He}$ articulated a two-part requirement, "first that a person [exhibit] an actual (subjective) expectation of privacy, and second, that the expectation be one that society is prepared to recognize as 'reasonable." 266

Significantly, the reasonable expectation of privacy test that Katz birthed is not a measure of the general issue, whether a governmental intrusion is unreasonable - for this inquiry, probable cause will sufficebut is rather a test of whether a warrant or any other qualification is even required in the first place. Had the FBI agents only taken the trouble to seek a warrant, the Katz Court suggests that they would have obtained one and the search would have been constitutional. ${ }^{267}$ " [I] n substituting reasonable expectations of privacy for property rights as the focus of fourth amendment protection, the Court was not substituting one inviolable interest for another," one commentator writes. "It appears that the Court now believed that the sole function of that amendment is to ensure that privacy is not invaded in an arbitrary manner, rather than to ensure that privacy receives absolute protection against invasion."268 The effect of this shift is to convert the Fourth Amendment inquiry into a probable cause test. This is not quite what the Boyd Court had in mind when it called the right

${ }^{262}$ Id. at 304

${ }^{263} 389$ U.S. 347 (1967).

${ }^{264}$ Id. at 351.

${ }^{265}$ See, e.g., Vernonia School District 47J v. Acton, 515 U.S. 646, 654 (1995); Terry v. Ohio, 392 U.S. 1,9 (1968).

${ }^{266}$ Katz, 389 U.S. at 361 (Harlan, J., concurring).

${ }^{267}$ See id. at 354-55.

${ }^{268}$ Note, The Life and Times of Boyd v. United States (1886-1976), 76 MicH. L. REV. 184, 203 (1977). 
protected by the Fourth Amendment "indefeasible," 269 nor what Justice Brandeis had in mind when he called the right to be let alone, as against the government, "the right most valued by civilized men." 270

With Hayden and Katz, the Court achieved Brandeis's vision of unmooring the Fourth Amendment from fetishistic property protection, but did not concomitantly maintain the heightened scrutiny that both the Boyd Court and Brandeis considered essential to the review of rights they thought fundamental. ${ }^{271}$ Thus, a doctrinal void was formed. Justice Stewart recognized as much when he wrote in Katz that "the Fourth Amendment cannot be translated into a general constitutional 'right to privacy. . . .' Other provisions of the Constitution protect personal privacy from other forms of governmental invasion." 272 Heightened protection of man's "spiritual nature",273 would be left to other constitutional provisions and their attendant jurisprudence.

\section{c. Fundamental Decision Privacy}

The development of a more transcendent constitutional right of privacy, of the sort envisioned by Brandeis in his Olmstead dissent, would come in 1963 , in Griswold v. Connecticut, ${ }^{274}$ though it was a long time in the making. Indeed, as early as 1914, Margaret Sanger had begun agitating for a woman's right to control her own fertility, in a self-published monthly magazine called The Woman Rebel. ${ }^{275}$ An obvious thread within the Warren and Brandeis conception of privacy as sovereignty over one's public image views being "let alone" not as an end in itself but as a means to personal autonomy. The Woman Rebel took as its subtitle "No Gods No Masters,"276 because privacy in its most transcendent form is about control. Woman, that is, should be the mistress of her own destiny, and repeal of the anti-birthcontrol laws was necessary to her emancipation from a form of economic

\footnotetext{
${ }^{269}$ Boyd, 116 U.S. at 630.

${ }^{270}$ Olmstead, 277 U.S. at 478 (Brandeis, J., dissenting).

${ }^{271}$ See Tracy Maclin, The Central Meaning of the Fourth Amendment, 35 WM. \& MARY L. REV. 197, 199 (1993) (suggesting that present Fourth Amendment doctrine most closely parallels rational basis review); see also Louis Henkin, Privacy and Autonomy, 74 ColuM. L. REV. 1410, 1425 (1974) (suggesting that fundamental decision privacy does not necessarily protect the more obvious invasions of privacy encompassed within the Fourth Amendment).

${ }^{272} \mathrm{Katz}, 389$ U.S. at 350.

${ }^{273}$ Olmstead, 277 U.S. at 478 (Brandeis, J., dissenting).

274381 U.S. 479 (1965).

${ }^{275}$ DAVID J. GaRROW, LIBERTY AND SEXUALITY: THE RIGHT TO PRIVACY AND THE MAKING OF ROE V. WADE 10 (1994).

${ }^{276}$ THE Woman ReBel, Mar. 1914, at 1, reprinted in Woman Rebel 1 (Alex Baskin ed., 1976) [hereinafter Baskin].
} 
slavery. Wrote Sanger in an editorial in the magazine's first issue, "No plagues, famines or wars could ever frighten the capitalist class so much as the universal practice of the prevention of conception."277

The application of the privacy right to contraception was the brainchild of Fowler Harper, a Yale Law School professor and anti-government gadfly. ${ }^{278}$ As counsel for the plaintiffs in Poe v. Ullman, ${ }^{279}$ the second of three direct legal challenges to Connecticut's anti-birth control laws, ${ }^{280}$ Harper devoted a section of his merits brief to the privacy rights of married people. He quoted Justice Brandeis's Olmstead dissent and argued that the Connecticut statute was a "colossal irrelevancy to any proper concern of the legislature of the State of Connecticut."281 The State, Harper urged, had an obligation to accord equal respect to the "conscience and beliefs" of those who believe in and wish to use contraceptives "in the privacy of the home." ${ }^{282}$ Although the Court dismissed Poe on standing grounds, ${ }^{283}$ Justice Douglas's dissent laid the seeds for a vast expansion of constitutional rights against the government. After quickly dismissing the justiciability issue as chimerical, he outlined the thick liberty interest for birth control patients that would soon command a majority. On Justice Douglas's view, the liberty of which the Due Process Clause speaks "is a conception that sometimes gains content from the emancipation of other specific guarantees or from experience with the requirements of a free society." 284 On this view, Lochner's fatal flaw was not that it attempted to inject substantive values into the due "process," but that it injected the wrong ones, namely economic rights. ${ }^{285}$ Certain other rights, those implicit in the language of other constitutional guarantees, should be guarded against state interference.

${ }^{277}$ Editorial, THE WOMAN REBEL, Mar. 1914, at 8, reprinted in Baskin, supra note 276, at 8. The Malthusian undertones of this rhetoric were self-conscious. See Clara Newcome, NeoMalthusianism-What Is It, THE WOMAN REBEL, May 1914, at 2, reprinted in Baskin, supra note 276, at 26.

${ }^{278}$ In 1944, Fowler resigned from the Indiana University Board of Trustees on suspicion of being a communist sympathizer. While at Yale, he had persuaded 22 of his colleagues to sign an open letter calling for the abolition of the House Un-American Activities Committee. See GARROw, supra note 275 , at $148-51$.

279367 U.S. 497 (1961).

280 The first was Tileston v. Ullman, 26 A.2d 582 (Conn. 1942), which the Supreme Court dismissed on standing grounds, 318 U.S. 44 (1943) (per curiam).

${ }^{281}$ Brief for Appellant at 28, Poe v. Ullman, 367 U.S. 497 (1961).

${ }^{282} I d$.

${ }^{283}$ The Court held that given that the only known prosecution under the anti-birth control statute was State v. Nelson, 11 A.2d 856 (Conn. 1940), no actual case or controversy was before the Court. Poe v. Ullman, 367 U.S. 497 (1961).

${ }^{284}$ Poe, 367 U.S. at 517 (Douglas, J., dissenting).

${ }^{285} I d$. 
Privacy, Justice Douglas wrote, is one such right. A statute forbidding use of contraceptives requires "an inquiry into the relations between man and wife" and therefore "is an invasion of the privacy that is implicit in a free society." ${ }^{286}$ Although Justice Douglas did suggest that the Connecticut statute was inconsistent with the spirit of the Third Amendment, ${ }^{287}$ he did not cull his support primarily from constitutional text. He cited instead to a long passage from an article in a journal called Natural Law Forum:

One of the earmarks of the totalitarian understanding of society is that it seeks to make all subcommunities - family, school, business, press, church - completely subject to control by the State. . . In a democratic political order, the megatherian concept is expressly rejected as out of accord with the democratic understanding of social good, and with the actual make-up of the human community. ${ }^{288}$

It hardly seems fitting to describe a statute that has been enforced once in eighty-one years in such Orwellian terms, but Justice Douglas's program was broader than one little blue law. To be sure, his particular account of the appropriate relationship between citizen and democratic government did not accurately describe the United States in 1960. Seven years before Loving v. Virginia, ${ }^{289}$ much of America could well be called "megatherian," and indeed the understanding of "social good" Justice Douglas would himself endorse thirteen years later in Roe v. Wade was not obviously democratic. But the anti-totalitarian, anti-control normative aspiration Justice Douglas's dissent represents captures much of what had motivated Sanger, and carries considerable purchase even today. ${ }^{290}$

When Griswold finally came down in 1965, then, it was anything but spontaneous. Justice Douglas's opinion for the majority made clear, if nothing else, that the right to privacy could not be cabined within a single constitutional norm. The First Amendment protections of associational rights, the Third and Fourth Amendment protections against government intrusion upon one's home and personal effects, and the Fifth Amendment

${ }^{286} I d$. at 521 .

${ }^{287}$ Id. at 522. The Third Amendment states: "No soldier shall, in time of peace be quartered in any house, without the consent of the Owner, nor in time of war, but in a manner to be prescribed by law." U.S. CONST. amend. III.

${ }^{288}$ Poe, 367 U.S. at 521-22 (Douglas, J., dissenting) (quoting Robert L. Calhoun, Democracy and Natural Law, 5 NAT. L.F. 31, 36 (1960)).

289388 U.S. 1 (1967)

${ }^{290}$ Justice Harlan dissented separately in Poe, but his opinion more directly invoked the doctrinal connection with the Fourth Amendment. Poe, 367 U.S. at 548-51 (Harlan, J., dissenting). 
protections of one's inner thoughts conspire to create "zones of privacy."291 Since Griswold, the Court has found that the constitutional right to what has come to be known as "fundamental decision" privacy protects the use of contraceptives by single people ${ }^{292}$ and minors; ${ }^{293}$ the ability of prisoners or those behind in their child support to marry; ${ }^{294}$ the possession of pornography in one's home; ${ }^{295}$ and, most controversially, a woman's decision to have an abortion. ${ }^{296}$ But the right does not, for example, extend to the decision to ask a physician to end one's own life, ${ }^{297}$ a family's decision to impose euthanasia without clear consent of the patient, ${ }^{298}$ or a parent's decision to send her child to a segregated school. ${ }^{299}$

In attempting to distinguish between those activities that are protected by the right to fundamental decision privacy and those that are not, the essential question is, what is the substance and scope of the ultimate end being protected? Margaret Sanger, Justice Douglas and, to a lesser extent, Justice Harlan articulated an anti-totalitarian vision concerned with the State's ability to control the lives of its constituents. On this view, certain rights, such as the family's inherent right to sovereignty, are less appropriately subject to political regulation than others. Fowler Harper embraced a more Lockean approach that, while not excluding the antitotalitarian view, emphasizes a woman's right to controvert the morals of the community as an exercise of her liberty of conscience.

In examining the extent to which these conceptions of privacy have survived doctrinally, the abortion cases give us considerable guidance. The holding of Roe v. Wade is complex and contestable, ${ }^{300}$ but its relevance to this paper is its declaration in clear terms remarkably similar to Lawrence that a woman's right to have an abortion is a constitutionally protected privacy right "founded in the Fourteenth Amendment's concept of personal liberty." "301 The decision whether to terminate one's pregnancy was deemed fundamental because of the impact childbirth can have on the mother's future life plans. Not only might pregnancy carry medical risks, but

\footnotetext{
${ }^{291}$ Griswold v. Connecticut, 381 U.S. 479, 484 (1965).

${ }^{292}$ Eisenstadt v. Baird, 405 U.S. 438 (1972).

${ }^{293}$ See Bolger v. Youngs Drug Prods. Co., 463 U.S. 60 (1983).

${ }^{294}$ Turner v. Safley, 482 U.S. 78 (1987); Zablocki v. Redhail, 434 U.S. 374 (1978).

${ }^{295}$ Stanley v. Georgia, 394 U.S. 557 (1969).

${ }^{296}$ Planned Parenthood v. Casey, 505 U.S. 833 (1992); Roe v. Wade, 410 U.S. 113 (1973).

${ }^{297}$ Washington v. Glucksberg, 521 U.S. 702 (1997).

${ }^{298}$ Cruzan v. Director, Mo. Dep't of Health, 497 U.S. 261 (1990).

${ }^{299}$ Runyan v. McCrary, 427 U.S. 160 (1976).

${ }^{300}$ Roe is more criticized than not by constitutional scholars, but for a particularly cogent critique, see John Hart Ely, The Wages of Crying Wolf: A Comment on Roe v. Wade, 82 YALE L.J. 920, 947 (1973) (calling Roe "bad constitutional law, or rather . . . not constitutional law").

${ }^{301}$ Roe v. Wade, 410 U.S. 113, 153 (1973).
} 
"[m]aternity, or additional offspring, may force upon the woman a distressful life and future," due to psychological stress, the burdens of child care, social stigma and the like. ${ }^{302}$ Presenting an abortion ban as working a kind of Hobson's choice illustrates Roe's connection both to Griswold and to Lawrence. As Sanger argued, a prohibition on contraceptives effects a form of slavery on women that forces them to choose between abstinence and child-bearing. As I argue in Part I, a prohibition on sodomy forces gays into a choice between criminality and the closet. ${ }^{303}$

Early in his Roe opinion, Justice Blackmun quotes Justice Holmes's celebrated Lochner dissent, in which Holmes says that the Constitution "is made for people of fundamentally differing views, and the accident of our finding certain opinions natural and familiar or novel and even shocking ought not to conclude our judgment . . ." "304 This use of Holmes highlights the fact that applying his words to morals legislation actually supports striking down the challenged statute. Balanced against a decision deemed fundamental because of its profound impact on the life of an individual, the moral qualms of the community seem cruel and trifling.

The most significant attempted restatement of Roe's animating principles came in Planned Parenthood v. Casey, in which a Court plurality changed Roe's categorical tripartite framework into an "undue burden" balancing test. ${ }^{305}$ Of most interest to my analysis is the sweeping language the plurality used to justify its reaffirmation of fundamental decision privacy as applied to the abortion decision. As with opinions past, the Court described the protected zone of privacy as "a realm of personal liberty which the government may not enter." 306 But just as Griswold construed that realm as transcending the physical curtilage of the home and reaching certain private choices by individuals, Casey extended Roe's protective net into more abstract space. In one of its most cited passages, the Court wrote that the issues to which a privacy right had been extended:

involv[e] the most intimate and personal choices a person may make in a lifetime, choices central to personal dignity and autonomy, [and] central to the liberty protected by the Fourteenth Amendment. At the heart of liberty is the right to define one's own concept of existence, of meaning, of the universe, and of the mystery of human life. Beliefs about these matters could not define the attributes of

${ }^{302} I d$.

${ }^{303}$ See text accompanying notes 59-60.

${ }^{304} \mathrm{Id}$. at 117 .

${ }^{305} 505$ U.S. 833 (1992).

${ }^{306}$ Id. at 847 . 
personhood were they formed under compulsion of the State. ... The destiny of the woman must be shaped to a large extent on her own conception of her spiritual imperatives and her place in society. ${ }^{307}$

Fundamental decision privacy, on this formulation, is not about "privacy" at all, at least not as conventionally understood. Until Casey, it was possible to view the Court's privacy decisions through a fictional prophylactic lens. Consider the following reading: The constitutional right of privacy protects against unwarranted physical invasions of the home. A statute barring the use of contraceptives, barring the viewing of pornography, or barring abortions cannot properly be enforced without a physical invasion of the home. Although Roe's language about the impact of child-bearing on the mother's life course undermines such a formalistic reading of the fundamental decision cases, such a reading still could serve to moor these cases to traditional notions of privacy grounded in physical space, and provide guidance in future decisions. Casey, however, linked fundamental decision privacy explicitly to concepts of autonomy, personal conscience, and self-definition. ${ }^{308}$

Bowers v. Hardwick had already been decided six years prior to Casey, which no doubt provided additional cover for the Casey plurality's openended claims about the nature of constitutional privacy. Bowers had drawn a line in the sand. To those who thought that the incremental logic of common lawmaking demanded a close examination of the asserted state interest in regulating private, consensual, non-commercial sexual conduct, Justice White's statement of the issue presented was more than mildly discouraging. ${ }^{309}$ The Bowers Court construed the doctrinal definition of fundamental rights- those "implicit in the concept of ordered liberty" 310 as limiting acts protected by substantive due process to those that were expressly permitted historically. But Lawrence vindicated the vision of privacy that Justice Blackmun stated succinctly in dissent:

\footnotetext{
${ }^{307} I d$. at 851 . This portion of the opinion was joined by Justice Blackmun and Justice Stevens and thus commanded a majority.

${ }^{308}$ Because Casey upheld controversial restrictions on abortion rights, political economy allowed and perhaps compelled the Court to speak in such far-reaching terms. See generally GARROw, supra note 275, at 700 (describing the reaction to Casey as follows: "Some pro-choice groups ... self-defeatingly tried to insist that 'Roe $v$. Wade is dead,' while right to life activists castigated the O'Connor-Kennedy-Souter trio as 'backstabbing' members of a 'wimp bloc.'”)

${ }^{309}$ See Bowers v. Hardwick, 478 U.S. 186, 190 (1986) (calling the issue "whether the Federal Constitution confers a fundamental right upon homosexuals to engage in sodomy").

${ }^{310}$ Palko v. Connecticut, 302 U.S. 319, 325 (1937).
} 
This case is no more about 'a fundamental right to engage in homosexual sodomy'... than Stanley v. Georgia was about a fundamental right to watch obscene movies, or Katz v. United States was about a fundamental right to place interstate bets from a telephone booth. Rather, this case is about 'the most comprehensive of right and the right most valued by civilized men,' namely, the right to be let alone. ${ }^{311}$

The majority framed the case as about the freedom to engage in sodomy. The dissent framed the case as about freedom to make fundamental personal decisions. The prophylactic fiction discussed above facilitated this debate by minimizing the individual interest to the interest of a gay person in having sex in his home, which is susceptible to interpretation as either more or less important than the community's interest in policing morals.

After Casey, however, privacy interests were expressly defined as the interests of all people in a measure of autonomy and self-definition. Thus stated, the form that self-definition takes is more obviously irrelevant to the constitutional analysis. The related anti-totalitarian view of privacy rights, which I have associated with Margaret Sanger and Justice Douglas, sees privacy as control of one's destiny. Understood in this way, privacy is instrumental to the prospective identity of the individual, not merely to her recreational choices.

\section{Hate Speech and the First Amendment}

The measure of the metaprivacy principle's fit with constitutional doctrine extends beyond the privacy cases. Justice Kennedy's rhetoric about freedom of conscience and belief, both in Lawrence and as a member of the Casey plurality, suggests a further connection between metaprivacy and the First Amendment. If First Amendment doctrine draws distinctions between criminal commitments and the ethical commitments of abortion-seekers and gays, then those distinctions should inform my analysis of metaprivacy. At the very least, it should make me wary of glossing over any potential distinctions within the privacy line of cases.

Viewpoint discrimination remains paradigmatically offensive to the First Amendment. ${ }^{312}$ Within a public forum, the State may no more disfavor

${ }^{311}$ Id. at 199 (Blackmun, J., dissenting) (citing Olmstead v. United States, 277 U.S. 438, 478 (1928) (Brandeis, J., dissenting)) (other citations omitted).

${ }^{312}$ See, e.g., Good News Club v. Milford Cent. Sch., 533 U.S. 98 (2001) (holding unconstitutional a public after-school program that prohibited a Christian group from using school facilities); Nat'l Endowment for the Arts v. Finley, 524 U.S. 569, 583 (1998) (holding that the statutory 
criminal advocacy than gay rights advocacy, abortion-rights advocacy, or black power. ${ }^{313}$ Indeed, even a Ku Klux Klan member shouting racist invective and agitating for "revengeance" before a burning cross to a group of armed followers cannot be convicted unless it can be shown that his advocacy not only "is directed to inciting or producing imminent lawless action," but that such advocacy "is likely to incite or produce such action." " 114 If the character of the committed murderer is precisely analogous to the words of the committed inciter, then a character-based penalty phase inquiry not intended to adduce a likelihood of imminent danger is inappropriate.

But the committed murderer is not, of course, analogous, at least not precisely. Our First Amendment doctrine historically has attempted to distinguish, as it must, between expressive speech and expressive conduct. Thus, in R.A.V. v. St. Paul, the Court struck down as unconstitutionally overbroad and content-based a St. Paul, Minn., ordinance that criminalized the display of a "symbol, object, appellation, characterization or graffiti, including, but not limited to, a burning cross or Nazi swastika, which one knows or has reasonable grounds to know arouses anger, alarm or resentment in others on the basis of race, color, creed, religion, or gender . . .. ${ }^{315}$ While conceding for decisional purposes that the statute was aimed at "fighting words," a category of regulable speech, ${ }^{316}$ the Court concluded that the ordinance was invalid because it "applies only to 'fighting words' that insult, or provoke violence, 'on the basis of race, color, creed, religion or gender." Indeed, it was precisely because fighting words constitute a category of regulable speech rather than a form of communication "entirely invisible" to the First Amendment that the ordinance was struck down. ${ }^{317}$

Contrast this approach with the Court's approach in Wisconsin $v$. Mitchell, in which a unanimous Court upheld a Wisconsin statute that enhanced the sentence of any criminal convict who intentionally selected his victim on account of "race, religion, color, disability, sexual orientation, national origin or ancestry." $" 318$ The defendant, who was black and had

requirement that the National Endowment for the Arts take "decency and respect" into consideration does not "engender the kind of directed viewpoint discrimination that would prompt this Court to invalidate a statute on its face"); R.A.V. v. St. Paul, 505 U.S. 377, 84 (1992) ("[T]he government may proscribe libel; but it may not make the further content discrimination of proscribing only libel critical of the government.").

${ }^{313}$ See Brandenburg v. Ohio, 395 U.S. 444 (1969).

${ }^{314} \mathrm{Id}$. at 447 (emphasis added)

${ }^{315} 505$ U.S. 377,380 (1992).

${ }^{316}$ See id. at 381.

${ }^{317}$ See id. at $383-85$.

${ }^{318} 508$ U.S. 476, 480 (1993). 
robbed and beaten a white boy apparently selected because of his race, argued that the statute impermissibly "punishes bigoted thought and not conduct." ${ }^{319}$ The Court disagreed, arguing that the statute "is aimed at conduct unprotected by the First Amendment." ${ }^{, 320}$ The fact that the statute took motive into account made it no different than Title VII of the Civil Rights Act, ${ }^{321}$ not to mention a host of ordinary criminal statutes. Accounting for motive does not alter the conduct-based character of the targeted action. As in the antidiscrimination context, the First Amendment is no defense to criminal conduct.

A robust speech-conduct distinction would provide a daunting obstacle, grounded in doctrinal integrity, to any argument for a metaprivacy defense to a character-based retributive death sentence. The distinction does not, however, adequately explain the doctrine, for the First Amendment in fact provides a defense to generally applicable laws regulating conduct, in the form of the right to expressive association. ${ }^{322}$ In Boy Scouts of America $v$. Dale, the Court upheld Boy Scouts of America's right to an exemption from New Jersey's public accommodations laws on the grounds that retaining an avowedly gay scoutmaster "would significantly burden the organization's right to oppose or disfavor homosexual conduct." ${ }^{, 323}$ Such a burden could only be justified through a searching strict scrutiny test satisfied only when enforcing the statute "would not materially interfere with the ideas that the organization sought to express." 324 Boy Scouts seems to imply a new constitutional defense to Title VII, ${ }^{325}$ unless its bona-fide occupational qualification defense miraculously dovetails with the newly thickened right to expressive association. If some principle distinguishes R.A.V. and Mitchell under the post-Boy Scouts constitutional order, it would not appear to be speech versus conduct.

Lawrence as metaprivacy recommends a way out of this doctrinal confusion. Like Boy Scouts, Lawrence allows an exemption from generally applicable, otherwise constitutional laws that regulate conduct. And like

\footnotetext{
${ }^{319} I d$. at 483 .

${ }^{320} \mathrm{Id}$. at 487.

${ }^{321} \mathrm{Id}$.

${ }^{322}$ See Jed Rubenfeld, The Anti-Antidiscrimination Agenda, 111 YALE L.J. 1141, 1157-58 (2002).

${ }^{323} 530$ U.S. 640, 659 (2000).

${ }^{324}$ Id . at 657 . Chief Justice Rehnquist argued in Boy Scouts that the Court was simply reaffirming a right it recognized in Hurley v. Irish-American Gay, Lesbian and Bisexual Group of Boston, 515 U.S. 557 (1995), which allowed the organizers of Boston's St. Patrick's Day Parade to avert Massachusetts antidiscrimination laws to prevent a gay-rights group from marching. Boy Scouts, 530 U.S. at 653-54.

${ }^{325}$ See David E. Bernstein, Antidiscrimination Laws and the First Amendment, 66 Mo. L. REV. 83 (2001).
} 
Boy Scouts, the exemption appears to be grounded not in a speech-conduct distinction but in an incidental-definitional distinction. ${ }^{326}$ The Boy Scouts Court took pains to inquire into the significance of the burden that allowing an openly gay scoutmaster would have on the Boy Scouts' expressive rights. ${ }^{327}$ A charitable reading of the case is that heterosexual propaganda is an essential part of the organization's message, and therefore that subjecting the organization to the state's antidiscrimination laws would defeat its right to self-definition. A right to expressive association may thus be re-characterized as a corporate right to metaprivacy.

I do not wish to overemphasize the links between metaprivacy and the First Amendment expressive association doctrine. My more modest objective has been to demonstrate that an open-ended tolerance for the most deeply unpopular of ethical commitments is consistent with the First Amendment, and that the fact that convicted criminals have engaged in conduct rather than speech does not defeat this consistency.

\section{B. The Presumptive Autonomy Ideal}

In the discussion thus far, I have consistently defended the view that, from the perspective of metaprivacy doctrine, no principled distinction may be drawn between sodomy and certain other forms of a priori criminal conduct. But before I commit myself to so controversial a view, I must consider whether principles of judicial legitimacy implore us to read a theoretical limitation into the doctrine even if the case law does not itself provide much satisfying instruction. There is, after all, an immense literature on the line of demarcation between legitimate and illegitimate normativity. Although here is not the place for a theoretical discursis on the range of acceptable ethical views, it may be useful to consider at least one defensible distinction, if only to provide a template for an alternative conception. We might, for example, define an ethical view as a fundamental moral claim that has an answer to what Christine Korsgaard calls "the normative question." 328 On this view, though it may be definitionally necessary that ethical claims "issue in a deep way from our sense of who we are," ${ }^{329}$ it is not sufficient. An ethical view must be more than simply held; it must be justified.

\footnotetext{
${ }^{326}$ See supra text accompanying notes 89-90.

${ }^{327}$ Boy Scouts, 530 U.S. at 650-56.

${ }^{328}$ Christine M. Korsgaard, The Normative Question, in THE SOURCES OF NORMATIVITY 7, 9-10 (Onora O'Neill ed. 1996).

${ }^{329} I d$. at 18.
} 
Korsgaard's four-part taxonomy of modern answers to the normative question will be helpful in illustrating what is meant by an ethical view. She divides theories of the sources of our ethical obligations into voluntarism, realism, reflective endorsement, and the appeal to autonomy. ${ }^{330}$ Where the voluntarist justifies normativity by its origin in superior authority; ${ }^{331}$ the realist does so through the irreducible fact of the existence of obligations; $;{ }^{332}$ and the proponents of reflective endorsement and the appeal to autonomy through forms of self-conscious introspection. ${ }^{333}$ All of the above accounts share an obvious and important feature. Though Hobbes and Kant, say, differed dramatically as to the source of our obligations towards othersone thought it extrinsic, the other quite the opposite - both allowed that we have them.

Now consider the claims of gays versus those of committed murderers. The first thing to recognize is that both are underdetermined as ethical claims. Neither the fact that an individual wishes to engage in sodomy nor the fact that one wishes to murder tells us very much about the individual's answer to the normative question. One may argue, however, that there is a

${ }^{330} I d$. at 19.

331 See, e.g., Thomas Hobbes, Leviathan 98 (Richard E. Flathman \& David Johnston eds., 1997) (1651) ("It is true that they that have soveraigne power, may commit iniquity; but not injustice, or injury in the proper signification."); SAMUEL PUFENDORF, OF THE LAW OF NATURE AND NATIONS 17 (Basil Kennett trans, 4th ed., 1729) ("For, since honesty (or moral necessity) and turpitude are affections of human deeds, arising from their agreeableness or disagreeableness to a rule, or a law; and since a law is the command of a superior, it does not appear how we can conceive any goodness or turpitude before all law, and without the imposition of a superior.").

${ }^{332}$ Writes Thomas Nagel, illustrating the Occam's razor-like quality of realist argumentation: If I have a severe headache, the headache seems to me to be not merely unpleasant, but a bad thing. Not only do I dislike it, but I think I have a reason to try to get rid of it. It is barely conceivable that this might be an illusion, but if the idea of a bad thing makes sense at all, it need not be an illusion, and the true explanation of my impression may be the simplest one, namely that headaches are bad, and not just unwelcome to the people who have them.

Thomas Nagel, The VieW from Nowhere 145-46 (1986); see also W.D. Ross, The Right AND THE GOOD 40 (1930) (“[W]hat we are apt to describe as 'what we think' about moral questions contains a considerable amount that we do not think but know, and . . this forms the standard by reference to which the truth of any moral theory has to be tested . . . ."); H.A. PRICHARD, Does Moral Philosophy Rest on a Mistake?, in MORAL OBLIGATION: ESSAYS AND LECTURES 1, 7 (1949) ("The sense of obligation to do, or of the rightness of, an action of a particular kind is absolutely underivative or immediate.").

333 See, e.g., IMmanuel Kant, Foundations of the Metaphysics of Morals 67 (Lewis White Beck trans., 1959) (1797) ("What else then can freedom of the will be but autonomy, that is, the property of the will to be a law to itself?"); JOHN RAWLS, A THEORY OF JUSTICE 11 (1971) (suggesting that the principles of justice be determined by "the choice which rational men would make in [a] hypothetical situation of equal liberty"); BERNARD WILLIAMS, ETHICS AND THE LIMITS OF PHILOSOPHY 117 (1985) ("[C]ritical reflection should seek for as much shared understanding as it can find on any issue, and use any ethical material that, in the context of the reflective discussion, makes some sense and commands some loyalty."). 
difference in that the claim of the committed homosexual is not inconsistent with an ethical view, while the claim of the committed murderer is. We might characterize the depravity inquiry at the penalty phase as, in effect, an effort to determine whether the convict considers himself to have obligations towards others. As Canadian psychologist Robert Hare has said, "There are some people for whom evil acts-what we would consider evil acts-are no big deal." ${ }^{\text {334 }}$ It is not implausible that an individual who can be so characterized has not satisfied the threshold of an ethical claim - that he accord some minimal level of moral respect to the claims of others - and therefore is not entitled to have his views respected. On this view, the committed murderer does not make a debatable claim, but rather makes none at all. Such an individual is to conduct as the obscene is to speech: "of such slight social value as a step to truth that any benefit that may be derived from [it] is clearly outweighed by the social interest in order and morality." 335 Does not a similar distinction in the realm of conduct better comport, if not with the constitutional doctrine, then at least with the theoretical assumptions of American law?

This Subsection argues that imputing such a distinction would be inappropriate. An attempt to articulate the limitations on claims to ethical autonomy that a government must respect begs the question. In order to reach what those limits are, one must first defend the proposition that there is a limit. A State in which all ethical claims are presumptively respected but may be overcome by protective concerns is not a fanciful aspiration. The task will be to explore how closely the aspirations implicit within our constitutional structure approximate this hypothetical State. I have argued that similar ideas lurk within the interstices of our privacy and First Amendment doctrines. The remainder of this Section looks to theory. I contend that the presumptive autonomy ideal that metaprivacy anticipates has considerable pedigree within the privacy literature. The burden is for the doctrine, prospectively, to prove these accounts and my own wrong.

Owing to Griswold and its progeny, the 1960s and 1970s were the heyday of privacy scholarship. As discussed in the previous Subsection, the case failed to announce a holistic theory of privacy. Rather, each of the Griswold opinions attempted to argue from doctrine why the right of married persons to use contraceptives was, in a sense, already constitutionally protected. In this way, Griswold was consistent with our common law juridical tradition of grounding both rules of decision and modes of analysis within a body of precedents. This tradition is part of what

\footnotetext{
${ }^{334}$ See Carey, supra note 7.

${ }^{335}$ Chaplinsky v. New Hampshire, 315 U.S. 568, 572 (1942).
} 
squares judge-made law with the democratic process: Cabining judicial decisionmaking within a universe of settled rules and principles perpetuates the fiction that judges are agents of constitutional law rather than its principals. When courts "announce" new rights, they tacitly invite conscientious observers to apply the principles that generate those rights to other contested areas of jurisprudence. Thomas Grey wrote in 1983 that "[f]rom the first, the Court's development of a right to privacy has suggested to philosophically minded commentators the possible elevation to constitutional status of Mill's principle of liberty." 336 This principle is the view that "the only purpose for which power can be rightfully exercised over any member of a civilized community, against his will, is to prevent harm to others." ${ }^{337}$ Constitutionalizing Mill's principle would have raised profound questions about the legitimacy of laws against drug use, prostitution, and a host of other arguably victimless crimes, and would have precipitated endless debate over the meaning of a "self-regarding act." 338 One can safely say, however, that Bowers shut the door on the harm principle. As doctrines mature, the rights-generating principles that spawned them crystallize into something closer to rules, and the scope of their ancillary application narrows.

Every now and again, however, a case like Lawrence comes along, in which the doctrine leaps to a new orbital, and a fresh set of commentary is spawned. This Subsection links Lawrence's constitutionalization of a principle of official neutrality with respect to self-defining conduct to previous privacy scholarship and to the larger philosophical debate about the nature of State power. I argue that, far from sui generis, Lawrence cements into doctrine one slice of a philosophical tradition whose adherents include Louis Henkin, Joel Feinberg and Jed Rubenfeld.

In order to place into perspective the body of privacy scholarship that best embraces Lawrence-style metaprivacy, it will first be helpful to discuss briefly some competing conceptions. One particularly inventive approach that remains influential is Charles Fried's idea of privacy as a form of social currency. Fried wrote his seminal article on the topic in 1968, three years after Griswold and one year after Katz, when privacy had "become the object of considerable concern." 339 Like Justice Kennedy, Fried views

\footnotetext{
${ }^{336}$ ThOMAs C. GRey, The LegAl EnForCEMENT OF MORALiTy 26 (1983).

${ }^{337}$ MILL, supra note 15 , at 80.

${ }^{338}$ Compare, e.g., Joel Feinberg, Offensive Nuisances, in PHILOSOPHY OF LAW 278 (Joel Feinberg $\&$ Jules Coleman eds., 2004) (highlighting nuisance as a problematic for Mill's principle), with HART, supra note 38 , at 42 (arguing for a strong public-private distinction in delineating selfregarding acts). One problem for both Mill and Hart is that they do not adequately explain why community sensibility, even with respect to private acts, cannot serve as a source of public duties.

${ }^{339}$ Fried, supra note 220, at 475.
} 
privacy as central to self-definition. The difference is that, for Fried, privacy is purely, but uniquely, instrumental to self-definition. Privacy preserves for the individual a sphere of exclusive personal knowledge. Fried treats this personal knowledge as a form of entitlement that the individual uses, in essence, to purchase the fundamental social bonds of love, friendship, and trust. ${ }^{340}$ Says he, "Privacy is not merely a good technique for securing these fundamental relations; rather without privacy they are simply inconceivable." ${ }^{341}$ Fried does not argue that his is the only way of understanding privacy, only that his is the only way that justifies the lofty status of the right to privacy. ${ }^{342}$

A "market conception of personal intimacy,"343 to the surprise of none, also emerges in Richard Posner's work in this area. Posner, though, views privacy not as an inflexible moral right but as a tradable entitlement best assigned to the party that will use the private information most efficiently. ${ }^{344}$ Neither Fried's nor Posner's "economic" view of privacy rights captures Justice Kennedy's concerns in Lawrence. Posner would subject privacy rights to the vagaries of the "market" for such rights. Fried's conception places restrictions on the valuable uses of privacy that Lawrence-style metaprivacy eschews. Lawrence prizes an autonomy of self-definition that is "transcendent," plausibly extending beyond love, friendship, and trust. Moreover, Fried's conception is overinclusive, in that it assigns a meaning to the alienation of one's privacy entitlement that may not always be present. $^{345}$ In any event, it is safe to assume that the Lawrence majority would reject the commodification of the right it seeks to protect. $^{346}$

Lloyd Weinreb, on the other hand, connects privacy explicitly to human autonomy. In this way, his conception seems more closely to approximate the metaprivacy ideal. He does not, however, believe that any rights necessarily follow from this conception. Weinreb writes that "privacy might be regarded as the face that autonomy presents to others similarly situated in the same community, merely one side of the abstract dichotomy between

\footnotetext{
${ }^{340}$ See id. at 484.

${ }^{341}$ Id. at 477.

${ }^{342}$ See id. at 484.

${ }^{343}$ Reiman, supra note 220, at 32.

${ }^{344}$ See Richard Posner, An Economic Theory of Privacy, Regulation, May-June 1978, at 19.

345 See, e.g., Reiman, supra note 220, at 33 ("One ordinarily reveals information to one's psychoanalyst that one might hesitate to reveal to a friend or lover. That hardly means one has an intimate relation with the analyst.").

${ }^{346}$ For a broad-ranging critique of this kind of rhetoric, see Margaret Jane Radin, MarketInalienability, 100 HARV. L. REV. 1849 (1987); Margaret Jane Radin, Property and Personhood, 34 STAN. L. REV. 957 (1982).
} 
public and private: Whatever is public is not private, and whatever is private is not public." 347 Taking as axiomatic that humans have something called "autonomy," and that it is this autonomy that enables them to be called individuals, Weinreb believes that privacy is a conventional label for this abstract notion. In this sense, neither privacy nor autonomy have any content nor can have any content. Rather, the public-private distinction is "scarcely more than [a] reminder[] that human beings are at one and the same time constituted as persons within a human community and autonomous." "348 If, as Lawrence seems to suggest, we believe that guaranteeing a limited freedom to engage in self-defining conduct is a public policy goal worth pursuing, then Weinreb's view suggests that we should simply pursue that goal directly. A recourse to a "right to privacy" gets us nowhere except, perhaps, rhetorically.

Fried, Weinreb, and others who do not view privacy rights as an independent value-holder are responding to an older intellectual tradition that sees privacy as both unique and valuable in many of the same ways as Justice Kennedy appears to. Privacy as autonomy is not a new idea. Adding "self-definition" to the definition borrows from those strands within the literature that connect privacy to "personhood." Roscoe Pound, for example, is an early proponent of the idea that the law of torts should protect an individual's "personality" interests, which include a right to physical integrity and personal liberty, a reputational right to personal honor, and a right to belief and opinion. ${ }^{349}$ Similarly, Jeffrey Reiman has advanced the proposition that privacy represents "a social ritual by means of which an individual's moral title to his own existence is conferred." That is, a thick sense of personal entitlement to one's thoughts, body and actions is necessary to the formation of "self." ${ }^{351}$ Whether conceptualized in terms of "personality" or "selfhood," it is easy to see how "privacy" rights applied against the government could eventually produce opinions like Roe and Lawrence. I do not deny that the privacy as "personhood" conception influences those opinions profoundly. I do want to suggest, though, that the

\footnotetext{
${ }^{347}$ Lloyd L. Weinreb, The Right to Privacy, in THE RIGHT TO PRIVACY 25, 31 (Ellen Frankel Paul et al. eds., 2000).

${ }^{348} I d$. at 34 .

${ }^{349}$ See Roscoe Pound, Interests in Personality, 28 HARV. L. REV. 343, 355 (1915).

${ }^{350}$ Reiman, supra note 220, at 39.

${ }^{351}$ Id.; see also Edward J. Bloustein, Privacy as an Aspect of Human Dignity: An Answer to Dean Prosser, in PHILOSOPHICAL DIMENSIONS OF PRIVACY: AN ANTHOLOGY 156 (Ferdinand David Schoeman ed., 1984) (arguing that public scrutiny creates conformity and thus makes us less differentiated as people); Rubenfeld, supra note 205, at $752 \mathrm{n} .93$ (collecting sources that equate privacy with "personhood").
} 
intellectual origins of Lawrence-style metaprivacy nest more precisely in the privacy as "autonomy" literature.

Louis Henkin offered one of the earliest defenses of the position that the legal concept of privacy post-Roe represents the moral freedom of an individual to pursue her own projects and plans. Writing in 1974, Henkin argued that the Supreme Court's recognition of privacy protected not "freedom from intrusion"-privacy's ordinary meaning — but "something farther-reaching, an additional zone of autonomy, of presumptive immunity to governmental regulation., ${ }^{352}$ Henkin traces the fundamental primacy of the individual lying behind substantive due process to our constitutional ideal of limited government. ${ }^{353}$ The "liberty" protected by the Fifth Amendment, Henkin says, echoing Justice Douglas's position in Poe, ${ }^{354}$ "did not mean Adam Smith but did mean John Stuart Mill." ${ }^{355}$ Henkin was not troubled by the constitutionalization of an open-ended, prima facie freedom from governmental regulation for certain ill-defined fundamental rights. ${ }^{356} \mathrm{He}$ saw it, rather, as a mandate to explore the "compelling state interest" side of the inevitable balance between private rights and public good. Instead of focusing all of our intellectual attention on defining the contours of the right, a potentially fruitless exercise, we should have a robust discourse about the ends for which society ever can intrude upon our individual autonomy. ${ }^{357}$

Joel Feinberg took the notion of privacy as autonomy a step further than Henkin. "If the privacy principle already attributed to the Constitution is not identical to personal sovereignty," he goes so far as to ask, "what can it be?"358 Feinberg argues that the Supreme Court's invocation of "privacy" is in fact the constitutionalization of what philosophers call "personal autonomy" or "self-determination," meaning "the sovereign authority to govern oneself, which is absolute within one's own moral 'boundaries.",359 These boundaries of personal sovereignty, Feinberg suggests, extend not just to the limits of the physical body but extend as well to "the right to

\footnotetext{
${ }^{352}$ Henkin, supra note 271, at 1411.

${ }^{353}$ See id. at 1412-13. Many would tether a constitutional respect for the natural rights of the individual to the stillborn Privileges or Immunities Clause of the Fourteenth Amendment rather than to substantive due process. See, e.g., Saenz v. Roe, 526 U.S. 489, 525 (1999) (Thomas, J., dissenting); AKHIL REED AMAR, THE BILL OF RIGHTS 163-80 (1998); JOHN HART Ely, DEMOCRACY AND DISTRUST: A THEORY OF JUDICIAL REVIEW 22-30 (1980).

${ }^{354}$ See supra note 285 and accompanying text.

${ }^{355} \mathrm{Id}$. at 1417.

${ }^{356}$ See id. at 1427.

${ }^{357}$ See id. at 1431.

358 Joel Feinberg, Autonomy, Sovereignty, and Privacy: Moral Ideas in the Constitution?, 58 NOTRE DAME L. REV. 445, 492 (1983).

${ }^{359} I d$. at 446-47.
} 
decide how one is to live one's life, in particular how to make the critical life-decisions." ${ }^{360}$ Like Henkin, Feinberg connects this idea of privacy explicitly to the philosophy of John Stuart Mill. He argues that Mill's sphere of self-regarding acts is a good rough cut at the limits of personal autonomy that the jurisprudential definition of privacy is attempting to substantiate: ${ }^{361}$ "respect for a person's autonomy is respect for his unfettered voluntary choice as the sole rightful determinant of his actions except where the interest of others need protection from him. ${ }^{\text {"362 }}$ Feinberg laments, however, that the Justices have too cavalierly recognized state power to counteract certain fundamental rights through morals legislation that "enforce[es] the requirements of decency;" 363 he would prefer a more absolute embrace of Mill.

Feinberg was writing before Bowers, Casey, and Lawrence, and so his positive description of American law comes with a significant caveat. We get farther with Jed Rubenfeld's conception of privacy. On Rubenfeld's account, privacy is best understood not as an individual right to personhood, autonomy or some other fundamental entitlement, but as a prophylactic against state tyranny. ${ }^{364}$ Writing three years after Bowers (but, presciently, three years before Casey), Rubenfeld found the analysis of both the majority and the dissents in that opinion lacking, namely because both called for arbitrary judicial decrees of the limits of the privacy principle under discussion. ${ }^{365}$ Why, for example, does fundamental decision privacy protect the right to engage in homosexual sodomy but not the right to engage in adultery or incest? ${ }^{366}$ Neither the "privacy as personhood" not the "privacy as autonomy" strands of the academic literature satisfactorily explain, for Rubenfeld, "which choices and decisions are protected." ${ }^{\text {"367 }} \mathrm{He}$ offers the following conception in response:

Anti-abortion laws, anti-miscegenation laws, and compulsory education laws all involve the forcing of lives into well-defined and highly confined institutional layers. At the simplest, most quotidian level, such laws tend to take over the lives of the persons involved: they occupy and preoccupy. They affirmatively and substantially shape a person's life; they direct a life's development along a

\footnotetext{
${ }^{360} I d$. at 454.

${ }^{361} I d$. at 487.

${ }^{362} \mathrm{Id}$. at 464.

${ }^{363}$ See id. at 488-89.

${ }^{364}$ See Rubenfeld, supra note 205.

${ }^{365}$ See id. at 747-50.

${ }^{366}$ See id. at 750.

${ }^{367} \mathrm{Id}$. at 751.
} 
particular avenue. These laws do not simply proscribe one act or remove one liberty; they inform the totality of a person's life. ${ }^{368}$

Although Rubenfeld explicitly rejects the application of metaprivacy to criminal commitments, ${ }^{369}$ I want to suggest that his totalitarian conception of privacy in practice effectuates the limited autonomy conception we see in Lawrence. Rubenfeld suggests that the novelty of his conception lies in the sharp distinction he draws between an inquiry into what the State is trying to forbid versus an inquiry into what the State is producing. ${ }^{370}$ Rather than trying arbitrarily to limit the conduct the State may regulate, he argues, we should instead reject governmental attempts to control the lives of citizens. As I argued in Section I.B, the most consistent justification Justice Kennedy offers for the majority position in Lawrence is that "[t]he State cannot demean [petitioners'] existence or control their destiny by making their private sexual conduct a crime. ${ }^{, 371}$ Because the conduct at issue was self-definitional, regulating it necessarily subordinated gay Americans' lives to the interests of the State-this was the linchpin of its unconstitutionality.

This idea is the centerpiece of Justice Douglas's Poe dissent: ${ }^{372}$ Rubenfeld's Orwellian state is the megatherian conception Douglas so feared. ${ }^{373}$ "By all accounts," says Rubenfeld, "privacy has everything to do with delineating the legitimate limits of governmental power." 374 Also coded within this idea is the quasi-First Amendment notion that we should be free to embody even unpopular conceptions of the good. Ruth Gavison has written that privacy crucially provides a context within which we can deliberate about potentially deviant ideas free from social pressure. ${ }^{375}$ Rubenfeld alludes to this freedom implicitly when he calls privacy "the fundamental freedom not to have one's life too totally determined by a progressively normalizing state." 376

Acting alone, the presumptive autonomy ideal provides only limited guidance to a judge deciding a hard case. Rubenfeld hopes that, by reconceptualizing privacy rights along anti-normativity lines rather than along fundamental-rights lines, he can escape Mill's and Feinberg's

\footnotetext{
${ }^{368}$ Id. at 784 .

${ }^{369}$ See supra text accompanying note 205 .

${ }^{370} \mathrm{Id}$. at 783 .

${ }^{371}$ Lawrence v. Texas, 539 U.S. 558, 578 (2003) (emphasis added).

${ }^{372}$ Poe, 367 U.S. at 521-22 (Douglas, J., dissenting).

${ }^{373}$ See supra text accompanying note 288.

${ }^{374}$ Rubenfeld, supra note 205, at 737.

${ }^{375}$ Ruth Gavison, Privacy and the Limits of Law, 89 YALE L.J. 421 (1980).

${ }^{376}$ Rubenfeld, supra note 205, at 784.
} 
jurisprudential problem. But even if Rubenfeld succeeds at capturing the common thread between laws against home schooling, abortion and sodomy-each "involve[s] a peculiar form of obedience that reaches far beyond mere abstention from the particular proscribed act"377 -his principle does no better than Mill's at deciding actual cases and controversies. Lawrence offers a solution to this problem through convention. Social consensus around the self-definitional nature of proscribed conduct triggers the presumptive protection against morals regulation to which Henkin, Feinberg and Rubenfeld attach normative value.

The doctrine may have an answer to the open-ended conception of metaprivacy that this paper has sketched. If presumptive autonomy means nothing else, though, it is that the doctrine bears the burden of articulating that answer. I began Section III.B with the briefest of snapshots of some theoretical answers to the normative question. The ethical theories that those answers represent are subtle and difficult. I discussed above what doctrine asks of its principles; ${ }^{378}$ navigating these subtleties is what principles ask of the doctrine that sustains them. It does not seem, after all, as if the inquiry into character at the penalty phase of a capital trial is designed to adduce whether the defendant's ethical views are consistent with the collective reflective equilibrium of mankind. It seems rather that society simply thinks it better that individuals with uncommonly and demonstrably vile character be dead than be alive. The doctrine must tell us why a legislative determination to give effect to this desire is sufficient for some conduct but not other conduct.

It is possible, finally, that gays are essentially constitutionally sui generis, that they are simply the sole members of the class of individuals granted the autonomy to engage in conduct prohibited by otherwise constitutional laws. For the Court to so declare would, however, require two traits neither of which its members possess in great abundance. The Justices would need the political courage to declare common law constitutionalism a fraud, and the deep sense of irony required to announce that gays share their constitutional singularity with the Boy Scouts of America.

\footnotetext{
${ }^{377} I d$. at 792-93.

${ }^{378}$ See supra text accompanying note 90.
} 


\section{CONCLUSION}

An eighteenth-century Englishman could have been hanged for "stealing property worth a shilling or more, setting fire to a heap of hay, breaking down the head of a fish pond so that the fish might escape, defacing Westminster Bridge [or] cutting a hop-bind in a hop plantation.,379 There are at least three reasons for this apparent brutality. First, prisons were far less developed then than now, and so capital punishment had fewer rivals. ${ }^{380}$ Second, it should be noted that the death penalty was used far less than it was authorized to be used: "[F]or most offenses, capital punishment was there primarily to serve as a deterrent and ... only a limited number of executions were necessary to bring this point home to the public." 381 Where alternatives to capital punishment are limited, that is, it is sensible to make all crimes capital but only punish a few. James Whitman highlights a third reason for the high number of capital crimes, but his is timeless: "Punishment," he notes, "puts people in their place."382 Whitman's (anthropological) claim is that "degradation in punishment is, and always has been, closely related to traditions and practices of social status." ${ }^{\prime 383}$ On this view, punishment acts as means of asserting social superiority.

Accepting Whitman's thesis makes it easy to see that prisoners and identity-based social movements share a common foe: the libidinal need to assert one's own moral superiority. The more we recognize this tendency, the more we must take care that law exercise its ordered violence to protect us, and not to sate us. Robert Cover reminds us that the "deliberate infliction of pain in order to destroy the victim's normative world and capacity to create shared realities we call torture" ${ }^{384}$ as well as law. H.L.A. Hart reminds us, in this regard, that the Nazis believed that "anything is punishable if it is deserving of punishment according "to the fundamental conceptions of a penal law and sound popular feeling." degrade Jews, gays, and prisoners, though obviously distinct in their particulars, are all influenced, heavily perhaps, by an inherent human desire to engage in ontological discrimination. Exorcising the fruits of this desire from law, as Mill and Brandeis recognized, is the great challenge of liberalism. Lawrence is a salvo in that struggle.

\footnotetext{
${ }^{379}$ JOHN BRIGGS ET AL., CRIME AND PUNISHMENT IN ENGLAND: AN INTRODUCTORY HISTORY 73 (1996).

${ }^{380}$ See id. at 82.

${ }^{381} \mathrm{Id}$. at 76.

${ }^{382}$ WHITMAN, supra note 164 , at 22.

${ }^{383} \mathrm{Id}$. at 26.

${ }^{384}$ Robert M. Cover, Violence and the Word, 95 YALE L.J. 1601, 1603 (1986).

${ }^{385}$ HART, supra note 338, at 12 (quoting Act of June 28, 1935).
} 
I have argued in this paper that Lawrence's doctrinal contribution is to constitutionalize official neutrality between substantive metacommitments, whether those commitments are to "gayness" or to a "depraved consciousness." Indeed, many will say these are one and the same, and have seen fit to legislate to that end. We can deploy the law's coercion as a response to antisocial conduct, of course, but to punish for dangerous character threatens to confuse normativity with homogeneity. I have not argued that the death penalty is per se unconstitutional. Proponents of judicial restraint will note that neither have I argued that Lawrence was correctly reasoned or even correctly decided. Had the case been decided on Equal Protection grounds, for example, this paper could not have been written. Part of my project, then, is to demonstrate the logical consequences of speaking in broad terms of an identity group to whom one is not prepared to extend the respect of heightened scrutiny.

This paper, then, is a challenge, not a conclusion. Each of its three Parts raises a number of difficult questions worthy of far more extensive treatment than a synthetic work of manageable scope can provide. I hope, at the very least, to have persuaded the reader that when we look past the political context in which Lawrence was written and pause to reorient its "historical mess," 386 we recognize a tension. Our jurisprudence is both notionally committed not to punish disfavored status and fundamentally committed both in practice and in theory not just to personal responsibility, but to personal blame, stubbornly insisting on the legal relevance of the content of one's character. The tension thus identified, the next move is the Court's.

${ }^{386}$ See UNGER, supra note 16, at 68. 